WIDER Working Paper 2014/102

\title{
Aid and environment in Mozambique
}

Alda Tomo ${ }^{1}$ and Nícia Giváa

August 2014 
Abstract: Mozambique benefits from environmental aid-related funds, but it is still unclear whether donor commitments render directly into projects that are copiously implemented for the purposes stated and what aid flows have actually been doing and are doing in the area of aid and environment in Mozambique. This study aims at determining what aid flows have actually been doing and to identify sectors prioritized by the donors. Additionally, the study assessed the trends in environmental issues in general, with emphasis to specific environmental issues, such as biodiversity, climate change, and desertification. Findings reveal that despite the extensive range of legal instruments to respond to the environmental call, only 9 per cent of the overall aid flows are allocated to environment-related issues.

Keywords: environmental aid, Mozambique, external funding, development aid JEL classification: F2, F3

Acknowledgements: This paper has been written as part of a collaboration between UNU-WIDER and the African Economic Research Consortium (AERC) within the UNUWIDER project 'ReCom-Foreign Aid: Research and Communication', directed by Tony Addison and Finn Tarp.

\footnotetext{
${ }^{1}$ Centre for Socio-Economic Studies (CESE), Institute for Agricultural Research of Mozambique (IIAM); ${ }^{2}$ Eduardo Mondlane University (UEM), Faculty of Agronomy and Forest Engeneering (FAEF), Division of Communication and Agrarian Sociology: corresponding author: alda.tomo@gmail.com
}

Copyright (C) UNU-WIDER 2014

ISSN 1798-7237 ISBN 978-92-9230-823-0

This study has been prepared within the UNU-WIDER project 'ReCom-Foreign Aid: Research and Communication', directed by Tony Addison and Finn Tarp.

Typescript prepared by Lisa Winkler at UNU-WIDER.

UNU-WIDER gratefully acknowledges specific programme contributions from the governments of Denmark (Ministry of Foreign Affairs, Danida) and Sweden (Swedish International Development Cooperation Agency-Sida) for ReCom. UNUWIDER also gratefully acknowledges core financial support to its work programme from the governments of Denmark, Finland, Sweden, and the United Kingdom.

The World Institute for Development Economics Research (WIDER) was established by the United Nations University (UNU) as its first research and training centre and started work in Helsinki, Finland in 1985. The Institute undertakes applied research and policy analysis on structural changes affecting the developing and transitional economies, provides a forum for the advocacy of policies leading to robust, equitable and environmentally sustainable growth, and promotes capacity strengthening and training in the field of economic and social policy-making. Work is carried out by staff researchers and visiting scholars in Helsinki and through networks of collaborating scholars and institutions around the world.

UNU-WIDER, Katajanokanlaituri 6 B, 00160 Helsinki, Finland, wider.unu.edu

The views expressed in this publication are those of the author(s). Publication does not imply endorsement by the Institute or the United Nations University, nor by the programme/project sponsors, of any of the views expressed. 


\section{List of Acronyms}

ACBF African Capacity Building Foundation

AERC African Economic Research Consortium

AfDB African Development Bank

AEO African Economic Outlook

BADEA Arab Bank for Economic Development

CDM Clean Development Mechanism

DNEAP Direcção Nacional de Estatística e Planificação

EC European Communities

GDP Gross domestic product

GEF Global Environmental Fund

GHG Greenhouse gas

ISDB Islamic Development Bank

LDC Least Developed Country

MDGs Millennium Development Goals

MICOA Ministry of Coordination of Environmental Affairs

MPD Ministry of Planning and Development

NAPA National Action Plan for Adaptation

NDF Nordic Development Fund

ODA Official Development Assistance

OFID OPEC Fund for International Development

OECD Organization for Economic Cooperation and Development

OPEC Organization of the Petroleum Exporting Countries

PAPA Action Plan for Agriculture Production

PARP Action Plan for Poverty Eradication

PARPA Action Plan for Eradication of Absolute Poverty

PEDSA Strategic Plan for the Development of Agricultural Sector

PEI Poverty and Environmental Initiative

PPCR Pilot Program on Climate Resilience

REDD Reduction of Emissions from Deforestation and Forest Degradation

UNAIDS Joint United Nations Programme on HIV/AIDS

UNDP United Nations Development Programme

UNFPA United Nations Population Funds

UNICEF United Nations Children's Funds

US United States

USAID US Agency for International Development

WFP World Food Programme 
Mozambique gained its independence from Portugal in 1975, which was followed by nearly two decades of civil war. The peace agreement was signed in 1992 and the country moved from a oneparty Marxist-Leninist ruling system to adopting a new constitution characterized by a multi-party system of democracy. During the last decade, Mozambique achieved an impressive average of 7.2 per cent growth (AEO 2012). According to AEO (2012), the high foreign direct investment inflows, mostly in extractive industries along with strong agricultural growth and infrastructure investments, have been the major drivers of growth in the last two years.

Despite its impressive economic growth, Mozambique is still one of the world's poorest countries and faces several development challenges. Poverty and chronic food insecurity are very high; about 55 per cent of the population is poor and 46 per cent of children under five years old are chronically malnourished (MPD/DNEAP 2010). According to the same document, the incidence of both poverty and malnourishment is particularly high in rural areas, where 70 per cent of households live: Virtually all of them (96 per cent) are engaged in agriculture, which is under-developed. Similarly to many other least developed countries (LDCs), official development assistance (ODA) is a major source of funding for public development programmes in Mozambique. For instance, aid flows covered about 51.4 per cent of the country's budget in 2010 (AEO 2012). In fact, according to AEO, Mozambique's main medium-term economic structural challenge is broadening its fiscal base (2012).

Poverty reduction has been a central focus of Mozambique's development strategy. Several development plans have been launched across the country; these include the National Action Plans for Eradication of Absolute Poverty (PARPA I, PARPA II, and PARP), along with other sectorial frameworks, such as Action Plan for Agriculture Production (PAPA), and Strategic Plan for the Development of Agricultural Sector (PEDSA), among others. Climate change poses a major environmental challenge to the country (AEO 2012). Until recently, environmental issues have not been holistically addressed within the context of sustainable development in Mozambique. However, currently the integration of environmental management into poverty reduction strategies and other development plans are being identified as a priority in the country's policy framework in order to ensure sustainable development. Yet, so far only an action plan for climate change has been approved: The government is currently preparing a strategic programme for climate resilience under the Pilot Program on Climate Resilience (PPCR) (AEO 2012).

In fact, due to the growing awareness and interest in environmental issues in the development arena together with Mozambique's increasing vulnerability to climate change and the recurrent occurrence of climate-related disasters, much attention and assistance addressing environmental issues have been given in the country. Since the severe flooding and cyclones in 2000, several aid and development agencies have been increasingly intervening in environmental related issues, such as humanitarian responses to natural disasters, natural resources protection, and preparedness for the challenges posed by climate change. Mozambique is one of the three African pilot countries selected for implementation of the Strategic Climate Fund of the Climate Investment Funds under which the PPCR is being implemented by the government with the support of the African Development Bank (AfDB), the World Bank, and the International Finance Corporation (AEO 2012). The objective of the PPCR is to deliver incentives for scaled-up action and transformational change through pilot projects that reveal how to integrate climate risk and resilience into basic development planning. According to AEO, the country is also actively making effort to reduce deforestation through the mechanisms of Reduction of Emissions from Deforestation and Forest Degradation (REDD). This initiative has enabled the execution of drought mitigating actions in the Limpopo basin in southern Mozambique as well as water conservation interventions in the central province of Tete (AEO 2012). 
Nevertheless, there is a lot of skepticism whether donor commitments render directly into projects that are copiously implemented for the purposes stated in the documents that describe the project. In fact, there is no clear picture regarding what aid flows have actually been doing and are doing in the area of aid and environment in Mozambique. There is a lack of clearly systematized information on actual shares of resources tackling environmental issues. Some databases on foreign aid, which are primarily based on commitments by the donors, are widely available. Still, no information is collected from the ground to complement these data in performance assessments. This desynchronized information at macro and micro levels creates a gap in planning and direct allocation of environmental aid into actual environmental action that the country is in need, making it difficult to monitor the performance of donor-funded activities. Hence, the African Economic Research Consortium (AERC) is undertaking a study in aid and environment in six selected countries, including Mozambique.

This country study is meant to determine what aid flows have actually been doing, and to identify the sectors prioritized by the donors in the country. In addition, the study intends to assess the trends in environmental issues in general and some specific environmental issues, such as biodiversity, climate change, and desertification for the donors targeting Mozambican development. The findings of this study might be helpful in bringing the reality from the ground as well as in following-up on commitments assessing disbursements and impacts.

This paper is organized into eight sections. The Section 2 presents the methodological approaches used, which include the description of the data sources, method of analysis, and some limitations of the study. Section 3 provides brief descriptions of the key environmental sectors in Mozambique. Section 4 provides a general overview on the Mozambican environmental policy framework and the fifth section focuses on the external funding in Mozambique, in terms of commitment and disbursement; the prioritized sectors of the economy, the major donors, and the level of actualization of their commitments. Section 6 highlights external funding addressing environmental issues, also in terms of commitment and disbursement, overall and in specific sectors of the economy as well as the major donors tackling environmental issues. Section 7 brings the views of the donors regarding aid and environment, and the final section provides the key remarks of the paper.

\section{Methodological approach}

The research consisted of two phases. The first phase included preliminary desk work to analyse both the context of environment in the policy framework and commitments from international donors across diverse sectors of the economy in Mozambique. Diverse documented data were used for this phase, however, it was heavily anchored on the AidData dataset (Tierney et al. 2011).

Based on the AidData dataset, the trend of financial commitment flows was assessed over time and across sectors. Still, it must be noted that this dataset might not completely cover all the development projects in the country. AidData is a very comprehensive and rich database and it contains information on development finance activities for the period of 1947-2011, including some environmental related information. A range of sources including the Organization for Economic Cooperation and Development (OECD) creditor reporting system, annual donor reports, project documents from bi- and multi-lateral aid agencies, as well as data gathered directly from donor agency sources, websites, and databases was used to compile the primary variable for the database.

Nevertheless, the improved AidData Research Release 2.1, used for this specific country study, presents some shortfalls. Due to its extensive size, it makes it difficult to handle and a lot of time 
is required to perform even very simple tasks, such as cut or copy. In addition, some inconsistencies regarding the variables codification were observed. Some codification of the environmental variables, such as biodiversity, climate, and desertification, were not in line with the variable environment. For instance, some projects coded as targeting at least one of the elements mentioned above were not coded as relevant for the variable environment. This called for further work on data cleaning, and checking for consistency across the variables in the database. Furthermore, not all projects were coded and classified.

Taking into account these difficulties/shortfalls and the impossibility of handling the more complete dataset through readily available software, an excel spreadsheet of all externally funded projects in Mozambique (from AidData) from 1996 to 2010 were transferred to STATA software in order to execute the required analysis. This dataset covered about 15,739 observations of projects funded by various donors in Mozambique during the period. Since not all the projects were coded in the original dataset, further coding work was performed for missing or correcting information. In some cases the projects were also organized in diverse sectors based on the title, description, and purposes provided in the original database. The overall analysis was mainly based on descriptive statistics and the output was summarized in form of tables or graphs.

The second phase of the study was based on the responses obtained through a survey administered to a number of selected donors using a structured questionnaire. About 12 development partners were purposely selected based on their cumulative contribution to the overall foreign development assistance over the time. However, the rate of response was very poor. Only three out of 12 selected partners responded to the questionnaire partially or completely. It was really challenging to engage the donors in this work. Most of the agencies are bureaucratic with unclear mechanisms for collaborating in research processes.

\section{Key environmental sectors in Mozambique}

The definition of environment in the Mozambican law include elements such as air, light, land, water, ecosystems, biodiversity, ecological relationships, organic and inorganic matter, as well as all socio-cultural and economic conditions that affect communities (Governo de Moçambique 1997). According to the constitution of the Republic of Mozambique, the citizens have the right to a balanced environment and the duty to protect the environment, while the state has the task to materialize these through the promotion of initiatives aiming at ecological equilibrium, conservation, and the preservation of nature (Governo de Moçambique 2004).

Nevertheless, Mozambique still faces challenges related to its historical under-development reflected by a high incidence of poverty and malnutrition, poor infrastructures, limited agricultural development, and wide gaps in educational achievements. The reliance of the majority of population on natural resources to sustain their livelihoods results in pressure on these resources, which leads to rapid environmental degradation. In general, Mozambicans livelihood is predominantly natural resource based, and hence highly sensitive to the impacts of climate and other environmental shocks. More than 80 per cent of the Mozambican population is engaged in subsistence farming.

The government's development plans acknowledge natural resources as one of the base resources for economic and social development. Therefore, natural resources need to be managed adequately in order to avoid their degradation, which would compromise the future of the current and subsequent generations. The environmental policy framework represents the base for sustainable development of the country, aiming at reducing poverty progressively and improving the livelihood while reducing environmental damage. The Ministry of Coordination of Environmental 
Affairs (MICOA) co-ordinates, advices, controls, and assesses the degree of the use of natural resources in Mozambique. Additionally, MICOA co-ordinates all environmental related actions in the country, ensuring the integration of environmental variables in the socio-economic development planning and management processes.

However, environmental issues are crosscutting between sectors. Not all actions addressing environmental issues in Mozambique are controlled by MICOA. Some environmental actions are mainstreamed in several relevant sectors of the economy. Therefore, to capture comprehensively the impact of external environmental aid in Mozambique, other key sectors of the economy need to be taken into consideration. In this section, brief descriptions of the key environmental related sectors of the Mozambican economy are presented.

\subsection{Agriculture}

Agriculture, including livestock, is still considered the foundation of the Mozambican economy since it employs the vast majority of the country's workforce. Agricultural croplands, grasslands, and pastures cover about 27 per cent of the land in the country (Marzoli 2007b). The Mozambican agricultural sector is mainly subsistence-based with limited use of improved technology. The majority of the activities is still based on small, hand-cultivated, and rain-fed units, with no application of improved inputs, and is mainly managed by women. With the large majority of agricultural production being rain-fed, weather variability is one of the major constraints of the production in the country. The livestock production is characterized by low investments in food supplementing, sanitary services, and animal husbandry. This has led to high rates of animal mortality related to diseases, lack of food, and predation.

The Agricultural sector, including livestock, is one of the most important sectors that directly threaten the environment. Activities performed in this sector can cause environmental degradation through conversion, loss, degradation, and fragmentation of natural ecosystems. For instance, the reliance on poor farming practices, such as slush-and-burn, by the majority of small-scale farmers, has been causing accelerated land degradation, soil quality depletion, and biodiversity loss in Mozambique. Additionally, poor performance in crop and livestock production has lead to overexploitation of forest resources, depleting rapidly the forests and causing accelerated biodiversity loss. Climate change has also been contributing to these effects.

Among other sectorial policy strategies, PEDSA was mainly developed for promoting environment-friendly practices. For instance, an emphasis was given to a shift towards sustainable agriculture and land use. Since then a number of projects implemented across the country promotes development of sustainable agriculture, such as conservation agriculture among other relevant practices. Conservation agriculture allows the small-scale farmers to increase soil fertility and crop yields on the same land, stabilizing the agricultural frontier and conserving the forests. However, the process of expansion of this practice across the country encounters numerous challenges since it requires the use of appropriate farming techniques as well as access to knowledge and appropriate technologies, including seed varieties.

Sustainable agricultural development requires concerted actions that not only target the improvement of environmental issues but also some related development issues, such as agricultural infrastructure, appropriate technology, efficient research and extension networks, integrated and improved process throughout the whole value chain, as well as land tenure and forest resource usage policies. Some of the priority actions in the agricultural sector include (i) expanding actions to stop forest conversion to agriculture and stabilizing the agricultural frontier; (ii) improving land use and planning; (iii) developing livelihood and economic alternatives/opportunities to destructive practices. 


\subsection{Forestry}

Mozambique is very rich in forest resources. The major forest ecosystems in Mozambique include Miombo woodland; coastal forests; Mopane woodland; grasslands, wooded savannas, Bushland; and Montane ecosystems. Forests cover an area of 406,000 km², about 51 per cent of the country; while other wooded formations (thickets, shrubs, and forests with shifting cultivation) cover around 147,000 $\mathrm{km}^{2}$, about 19 per cent of land in the country (Marzoli 2007b).

Miombo woodland, also known as Savannah woodland, is the predominant terrestrial ecosystem type in Mozambique (USAID 2013). It is dry tropical woodland, adapted to the generally poor soil and strongly seasonal rainfall regime, which is dominated by species of broad-leaved trees in the legume sub-family called Caesalpinioideae (Timberlake and Chidumayo 2011; Byers 2001).

The country holds a total of 13,400 $\mathrm{km}^{2}$ of coastal forests (Marzoli 2007b), mainly found from the northern border to the Zambezi River. This ecosystem is considered by Conservation International to be a global biodiversity hotspot-an area of high diversity and endemism under increasing threat. The threat to this ecosystem is exacerbated by the expansion of development and exploitation of natural resources (USAID 2013). Seven coastal forest species were recently assessed as endangered (Timberlake et al. 2011).

Mangrove ecosystems are one of the most important ecosystems in the country. Their conservation and restoration represents an important opportunity to demonstrate the value of an ecosystem-based approach to climate change adaptation. This ecosystem provides physical protection from cyclones, winds, waves, and storm surges and has the ability to trap and hold sediment and thereby build land. These ecosystems increase the resilience of coastal communities. Thus, the measures to reduce deforestation and forest degradation in mangroves, and/or to restore mangrove allow climate change adaptation and mitigation as well as biodiversity conservation.

The estimated annual rate of deforestation during the period between 1990 and 2002 was 0.58 per cent (Marzoli 2007a). The major causes of deforestation and forest degradation include clearing for agriculture (shifting cultivation), firewood collection, and charcoal production for commercial purposes, forest fires, hunting based on traditional techniques (use of fire), exploitation of construction material, timber harvesting, and establishment of commercial forest plantations.

The REDD initiative is being implemented across the country to forge sustainable use of natural resources including a payment system for environmental services. This initiative needs to be expanded for a broader coverage. In addition, there is a need to strengthen the capacity of communities and civil society organizations for meaningful engagement in environmental decision-making; community-based forest resources management deserves particular attention.

\subsection{Fisheries}

Mozambique is very rich in fishing resources, with coastline along the Indian Ocean of over 2,750 $\mathrm{km}$ and a marine exclusive area of $572,000 \mathrm{~km}^{2}$. The coastal and marine ecosystems offer resources, such as coral reefs, mangroves, and sea-grass beds that are extremely important for income generation, food security, and nutrition. Over two-thirds of the Mozambican population lives within $150 \mathrm{~km}$ of the coast, and the diverse fish and shellfish caught by artisanal fisheries are an important source of both protein and employment, contributing greatly to food security and nutrition for a large fraction of the coastal population.

In addition, the country has extensive freshwater and wetland ecosystems, such as rivers and their riparian zones as well as deltas, natural and artificial lakes created by dams, which have a relevant 
role in the provision of fresh water fish. Lake Niassa, Zambezi Delta, and Cahora Basa Lake are some of the freshwater and wetland ecosystems in Mozambique that are well- acknowledged nationally, regionally, and internationally in the fishery industry.

The sector of fisheries has an important role in income diversification, not only for people living in the coastal area but also for people living in the inland with access to water bodies; especially in the context of climate change, in which agriculture is becoming increasingly risky. However, the Mozambican fisheries sector is still underdeveloped representing only about 3 per cent of Mozambique's gross domestic product (GDP). The majority of the Mozambicans use artisanal tools in their fishing activities. One of the major challenges within this sector is illegal fishing, which leads to severe overfishing. There is a lack of knowledge that translates into use of inappropriate fishing gear and a weak capacity to inspect fishing (Government of Mozambique 2012). Climate change also poses a challenge to the fisheries sector as more people are relying increasingly on this activity for their livelihood. This also leads to the overexploitation of fish, even fingerlings which are important for ensuring sustainability.

To overcome the challenges facing the fisheries sector, efforts to promoting sustainable fishing are being carried out across the country. These include the promotion of aquaculture activities, the education of communities on sustainable fishing through community-based management, and the improvement of fishing regulations.

\subsection{Transport}

The transportation sector is one of the major sectors contributing to air pollution. A functioning and effective transport system is vital for broader economic development, including human development. In Mozambique, different types of means are operated; these include road, rail, water, and air transportation. In general, all the transportation infrastructures are underdeveloped. Road transportation dominates the sector, handling the majority of the transportation services and serving the majority of the population. Mozambique's transport system tends to serve mainly the major cities neglecting the rural areas, which have poorly developed infrastructure.

Since the country's independence in 1979, very few paved roads and railway tracks have been constructed across the country, and the majority of the existing ones have been increasingly degrading. Very little has been done on the rehabilitation and maintenance of the roads, railways, etc. The majority of the roads in the country are non-paved, and therefore, very costly to maintain. Additionally, most of them are non-accessible in some periods of the year. In fact, the poor development of transport infrastructures is one of the major bottlenecks of development of the country. For instance, poor linkages between major agricultural producing areas with major consumption areas result in high agricultural transaction costs that hinder agricultural development and consequently the overall economic development in the country. These problems are exacerbated by climate change, as recurrent floods are destroying the already precarious transport infrastructures.

Even in urban areas this sector has not been given the needed attention. The transportation services across the country are very inefficient, mainly due to poor investment and precarious road conditions. This has been leading to rapid proliferation of the use of private cars, which are environmentally inefficient. The major challenge is to promote investments in construction of new paved roads and to rehabilitate the existing ones to encourage a more competitive engagement of the private sector in the transportation services provision and creation of cycling paths. There is also a need of regulations that integrate more effective and transparent private transportation services provision, and taxation that encourages the use of more environmentally efficient means of transportation. 


\subsection{Energy resources}

The energy usage also has implications on the environment. Energy is an important and indispensable factor in the life of Mozambicans; regardless of social stratum and, it is one of the major challenges in the context of climate change and preservation of nature and humanity (Government of Mozambique 2012). Mozambique has abundant and yet largely unexplored renewable and non-renewable energy resources. For many decades the energy sector was characterized by decline, disruption, and initial post-war reconstruction. Until recently, the country's focus has been on hydro and coal mega power plants, which only reached a very limited portion of the population. In fact, while the country hosts one of the largest hydropower plants in Africa (Cahora Bassa hydro dam), only a small portion of the Mozambican households has access to electricity. The majority of the population has been relying on forestry resources as sources of energy; According to the Government of Mozambique (2012), about 81 per cent of the population depend on energy from biomass. This has lead to severe deforestation and biodiversity loss problems.

Nevertheless, this situation is now changing rapidly. Massive investments have been inserted in the electrification activities. The government programmes covered the promotion of electricity generation projects; the expansion of the national electricity grid and the extension of rural electrification, prioritizing the connection of more districts and consumers to the national grid (Government of Mozambique). According to the same document, the government has been promoting the construction of facilities to transport and store petroleum products and promoting the expansion of liquid fuel distribution networks to the poorest zones. Also, the country holds large sedimentary basins of natural gas and coalmines, and the exploration of these resources are emerging as important. There are already a number of megaprojects established in the country, but also an ongoing search in the Rovuma basin for gas and oil reserves. Nevertheless, there is still a need of improvement of regulations' framework and their enforcement strategies to ensure less harm to the environment.

Besides, the country has plenty of wind, water, and solar resources to generate cleaner energy - so far barely utilized due to undeveloped and inadequate infrastructure. This area offers opportunities for investment, since the country can take advantage of those existing renewable energy resources to foster sustainable development.

Fortunately, the country has started to take environmental issues into consideration and measures to minimize the negative environmental impacts are being considered in the exploration of existing resources. The need to replace dirty sources of power is creating incentives to resort to cleaner energy, such as solar and wind energy. Also, there are some investments on technological options to improve wood fuel efficiency and alternative energy sources to wood and charcoal. The government has invested in disseminating the use of improved technologies for the production and use of fuel wood; experiences in the use of solar power are being consolidated under the Millennium Villages project as well as in the supply of energy to health units without access to the national electricity grid; in 2010 there were already 29 biofuel projects in the country (13 to produce ethanol and 16 for biodiesel) (Government of Mozambique 2012).

\section{$4 \quad$ Mozambique's environmental policy framework}

Following the Rio summit in 1992, Mozambique ratified the three conventions-on Climate Change and Biological Diversity in 1995 and on Combat to Desertification and Drought in 1996. However, environmental issues were weakly defined and not well integrated in the priority sectors 
chosen for PARPA I. In response to Millennium Development Goals (MDGs) 1 to 71 in 2001, an increasing attention was paid to the relationship between poverty and environment in order to ensure environmental sustainability. Thus, the country's sectorial policy was renewed. In 2005, MICOA approved a renewed sectorial policy act that defines the nature, attributions, and competences of MICOA (Diploma Ministerial No 259/2005). In this policy act, the actions of MICOA are categorized into five sections: (i) inter-sectorial co-ordination of environmental affairs; (ii) environmental research, planning, and management; (iii) planning and land use; (iv) environmental impact assessment; (v) environmental promotion, education, and disclosure; and (vi) environmental inspection and supervision.

In addition, the Poverty and Environment Initiative (PEI) phase 1 was launched in collaboration with MICOA and the Ministry of Planning in 2005. A second phase of this initiative was started in 2008-10 after an overall evaluation of the MDGs, which revealed that goal 7 was far from being accomplished and more efforts were needed. In addition, under the Convention on Climate Change the government created an inter-institutional working group integrating different ministries, private sector actors, and civil society organizations. With the main objective of mainstreaming climate change into sector plans, the group was engaged in preparing the national capacity for the implementation of the Clean Development Mechanism (CDM) and in the elaboration of the National Action Plan for Adaptation (NAPA). In December 2007, the government approved NAPA, which targets four major areas: early warning; agricultural production; water resources management; and coastal zones (MICOA 2007).

Beyond CDM and NAPA, the government through MICOA has produced different legal instruments related to climate change and sustainable development. These include: (i) regulation for environmental quality standards and emissions; (ii) regulation for environmental inspection; (iii) environmental strategy for sustainable development; (iv) environmental law; (v) environmental impact assessment regulation; (vi) land regulation; (vii) land legislation; (viii) water resources legislation; (ix) energy policy; (x) national programme for environmental management; (xi) regulation for mine activities; and (xii) territorial planning law.

In addition, for the past two years the working group was active preparing a REDD strategy. The main objective of REDD is to forge a sustainable use of natural resources including a payment system for environmental services in Mozambique (MICOA 2010). Furthermore, the government has recently, in November 2012, approved the National Strategy for Climate Change Adaptation and Mitigation (2013-15) aiming at facilitating and promoting harmonious development and resilience to climate change and mechanisms for energy efficiency and sustainable use of natural resources.

In terms of policy framework, much has been done in the realm of environment. However, there is still a need to improve the enforcement of existing environmental laws and to build the capacity of communities and civil society entities for meaningful engagement in environmental decisionmaking (USAID 2013). Also, the co-ordination and harmonization of the actions of relevant ministries and agencies is important for the development of a functional institutional structure for sustainable environmental management.

\footnotetext{
1 MDG 1 to 7 are: (1) To eradicate extreme poverty and hunger; (2) To achieve universal primary education; (3) To promote gender equality and empower women; (4) To reduce child mortality; (5) To improve maternal health; (6) To combat HIV/AIDS, malaria, and other diseases; (7) To ensure environmental sustainability.
} 
The results of analysis of AidData reveal that during the period from 1996 to 2010, the donors have committed to finance Mozambique with a cumulative value of at least US $\$ 30,017$ million (US\$2009). However the country has only benefited from a cumulative amount of about US $\$ 9,249$ million (US\$2009), which correspond to about 31 per cent of the committed amount. Overall, the level of fulfillment of the commitments by the donors is quite low.

In addition, the trend analysis of the amounts of commitment reveals an accelerated increase between 1996 and 2007, with some discontinuity in 2003 (Figure 1). The highest amount of commitment by the donors was observed in 2008. From 2007 to 2008, the amount of donors' commitments reduced drastically and stabilized in 2010. Regarding the disbursement, two distinct periods can be distinguished, 1996-2003 and 2003-10. Each period shows an increasing trend reaching the highest point, which is then decreasing.

Figure 1: Trend of external funds

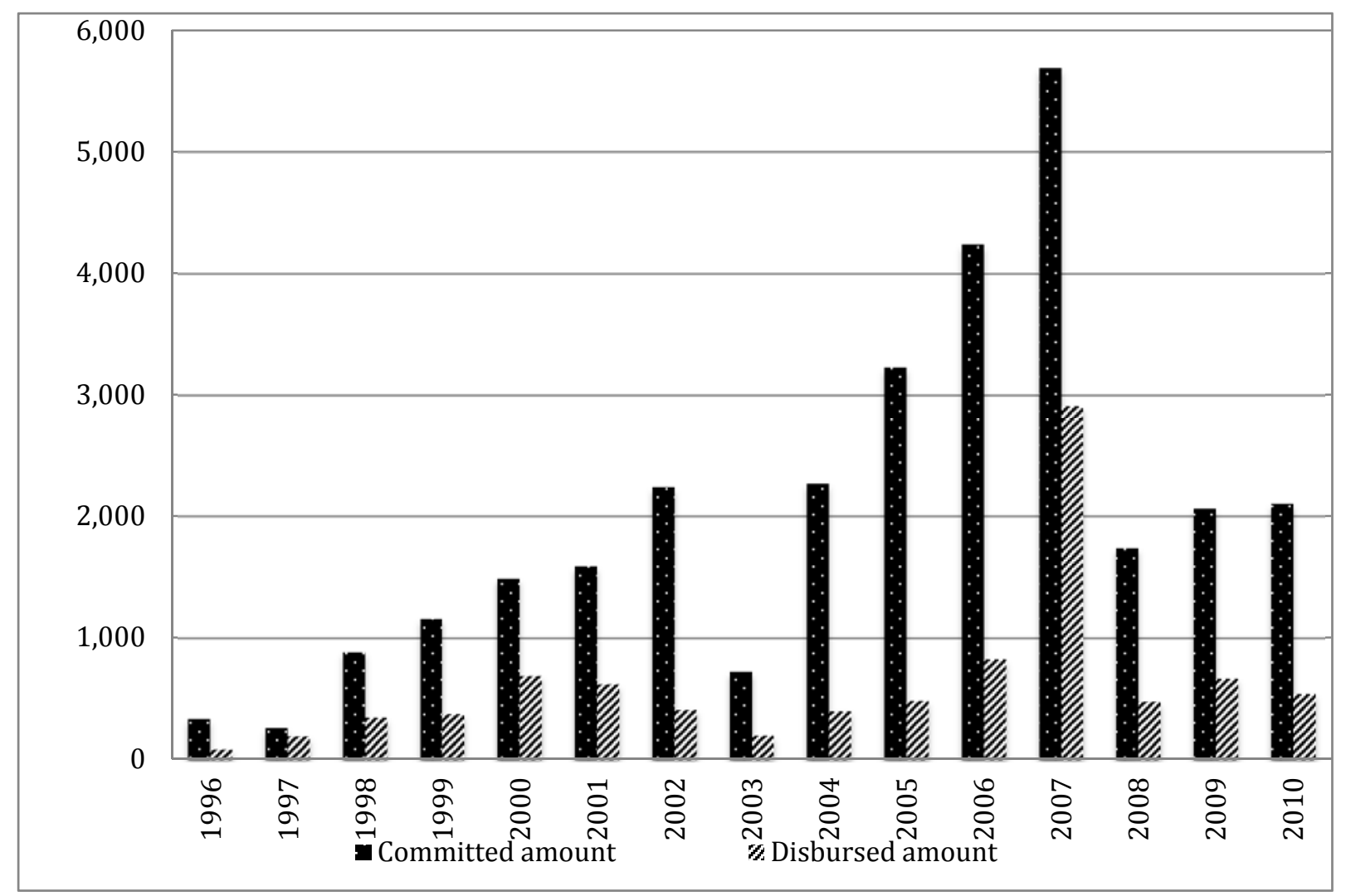

Source: Data based on Tierney et al. (2011).

Leaving aside the 'others' category, the results of analysis of AidData in the period of analysis clearly reveal that donors have prioritized investments in basic sectors such as health, education, economic development, and administration, either in terms of commitments or in terms of disbursements. These sectors of the economy present the largest amounts of commitment and disbursement. Agriculture, water resources and sanitation, infrastructures and transports, minerals and energy, as well as emergency aid and other welfare/social services seem to be important in donors' planning considerations. These findings are understandable since all these sectors are also the priority sectors of the Action Plan for Poverty Reduction. 
Figure 2: External aid commitment and disbursement by sector

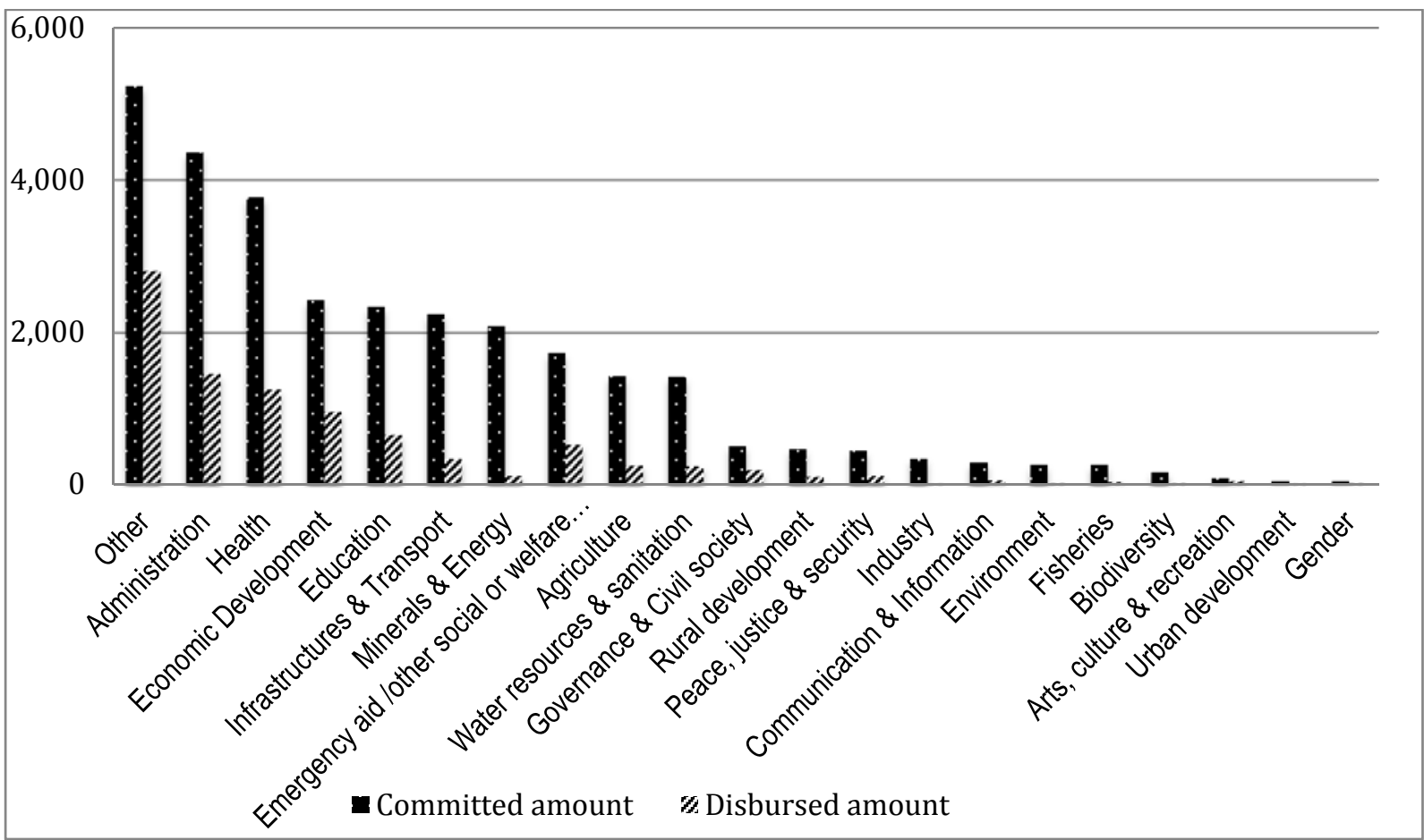

Source: Data based on Tierney et al. (2011).

The top 30 donors in Mozambique during the period 1996-2010 are presented in Table 1, and altogether, they account for about 99 per cent of the overall aid flows. Ireland, Portugal, UNICEF, Spain, United States (USA), and Sweden stand out with individual disbursements over 5 per cent of the total amount disbursed during this period. Altogether these six donors add up to about 61 per cent of the amount disbursed in the period of the study.

In terms of actualization of the commitments, UNICEF, European Communities (EC), Liechtenstein, Iceland, Chile, and the African Capacity Building Foundation (ACBF) stand outthey disbursed more than 50 per cent of the amount of their commitments. The group of donors, such as Portugal, France, Switzerland, Belgium, Austria, Denmark, United Kingdom, and the World Bank disbursed less than 50 per cent of the amount they committed. Nevertheless, the level of actualization of their commitments was greater than the overall level of 31 per cent. The remaining major donors present lower level of actualization of their commitments than the overall level. 


\begin{tabular}{|c|c|c|c|c|c|c|}
\hline Rank & Donor & $\begin{array}{l}\text { Amount committed } \\
\text { (US\$ 2009) }\end{array}$ & $\begin{array}{l}\text { Share of total } \\
\text { commitment (\%) }\end{array}$ & $\begin{array}{l}\text { Amount disbursed } \\
\text { (US\$ 2009) }\end{array}$ & $\begin{array}{l}\text { Share of total } \\
\text { disbursement (\%) }\end{array}$ & $\begin{array}{l}\text { Actualization of } \\
\text { commitment (\%) }\end{array}$ \\
\hline 1 & Ireland & $4,230,000,000$ & 14.09 & $1,730,000,000$ & 18.71 & 40.90 \\
\hline 2 & Portugal & $3,170,000,000$ & 10.56 & $1,210,000,000$ & 13.08 & 38.17 \\
\hline 3 & UNICEF & $1,760,000,000$ & 5.86 & $995,000,000$ & 10.76 & 56.53 \\
\hline 4 & Spain & $2,610,000,000$ & 8.70 & $708,000,000$ & 7.66 & 27.13 \\
\hline 5 & United States & $2,390,000,000$ & 7.96 & $547,000,000$ & 5.91 & 22.89 \\
\hline 6 & Sweden & $1,780,000,000$ & 5.93 & $471,000,000$ & 5.09 & 26.46 \\
\hline 7 & Norway & $1,910,000,000$ & 6.36 & $420,000,000$ & 4.54 & 21.99 \\
\hline 8 & Germany & $1,570,000,000$ & 5.23 & $413,000,000$ & 4.47 & 26.31 \\
\hline 9 & France & $922,000,000$ & 3.07 & $315,000,000$ & 3.41 & 34.16 \\
\hline 10 & Italy & $1,890,000,000$ & 6.30 & $302,000,000$ & 3.27 & 15.98 \\
\hline 11 & Switzerland & $819,000,000$ & 2.73 & $265,000,000$ & 2.87 & 32.36 \\
\hline 12 & Belgium & $670,000,000$ & 2.23 & $229,000,000$ & 2.48 & 34.18 \\
\hline 13 & EC & $284,000,000$ & 0.95 & $207,000,000$ & 2.24 & 72.89 \\
\hline 14 & The Netherlands & $1,230,000,000$ & 4.10 & $194,000,000$ & 2.10 & 15.77 \\
\hline 15 & Austria & $496,000,000$ & 1.65 & $170,000,000$ & 1.84 & 34.27 \\
\hline 16 & UNFPA & $768,000,000$ & 2.56 & $157,000,000$ & 1.70 & 20.44 \\
\hline 17 & Denmark & $375,000,000$ & 1.25 & $140,000,000$ & 1.51 & 37.33 \\
\hline 18 & Finland & $463,000,000$ & 1.54 & $116,000,000$ & 1.25 & 25.05 \\
\hline 19 & Canada & $625,000,000$ & 2.08 & $113,000,000$ & 1.22 & 18.08 \\
\hline 20 & UNDP & $466,000,000$ & 1.55 & $112,000,000$ & 1.21 & 24.03 \\
\hline 21 & Japan & $481,000,000$ & 1.60 & $92,000,000$ & 0.99 & 19.13 \\
\hline 22 & United Kingdom & $234,000,000$ & 0.78 & $79,500,000$ & 0.86 & 33.97 \\
\hline 23 & Australia & $219,000,000$ & 0.73 & $62,800,000$ & 0.68 & 28.68 \\
\hline 24 & Liechtenstein & $49,500,000$ & 0.16 & $32,800,000$ & 0.35 & 66.26 \\
\hline 25 & World Bank & $59,849,133$ & 0.20 & $22,653,588$ & 0.24 & 37.85 \\
\hline 26 & Iceland & $22,300,000$ & 0.07 & $19,100,000$ & 0.21 & 85.65 \\
\hline 27 & Chile & $23,200,000$ & 0.08 & $18,300,000$ & 0.20 & 78.88 \\
\hline 28 & ACBF & $18,100,000$ & 0.06 & $18,000,000$ & 0.19 & 99.45 \\
\hline 29 & Brazil & $114,000,000$ & 0.38 & $14,400,000$ & 0.16 & 12.63 \\
\hline 30 & AFDB & $122,100,000$ & 0.41 & $13,719,433$ & 0.15 & 11.24 \\
\hline
\end{tabular}

Source: Data based on Tierney et al. (2011).

\section{$6 \quad$ Environmental aid}

The analysis shows that the cumulative amount (1996-2010) of aid committed to address environmental issues revolves around US $\$ 3,145$ million. However, only US $\$ 557$ million was actually disbursed to address environmental issues. The level of actualization of commitments among projects that address environmental issues was about 18 per cent. In addition, the analysis of total aid shares reveals that for both externally committed and disbursed funds, the portion allocated to environmental issues is quite low (Figures 3 and 4). Only 7 per cent of the committed amount during this period addresses environment as a significant issue and only 3 per cent tackle explicitly environment as a main objective (Figure 3). The relevance of environmental issues compared to other development issues is fairly smaller in the disbursed of funds (Figure 4). 


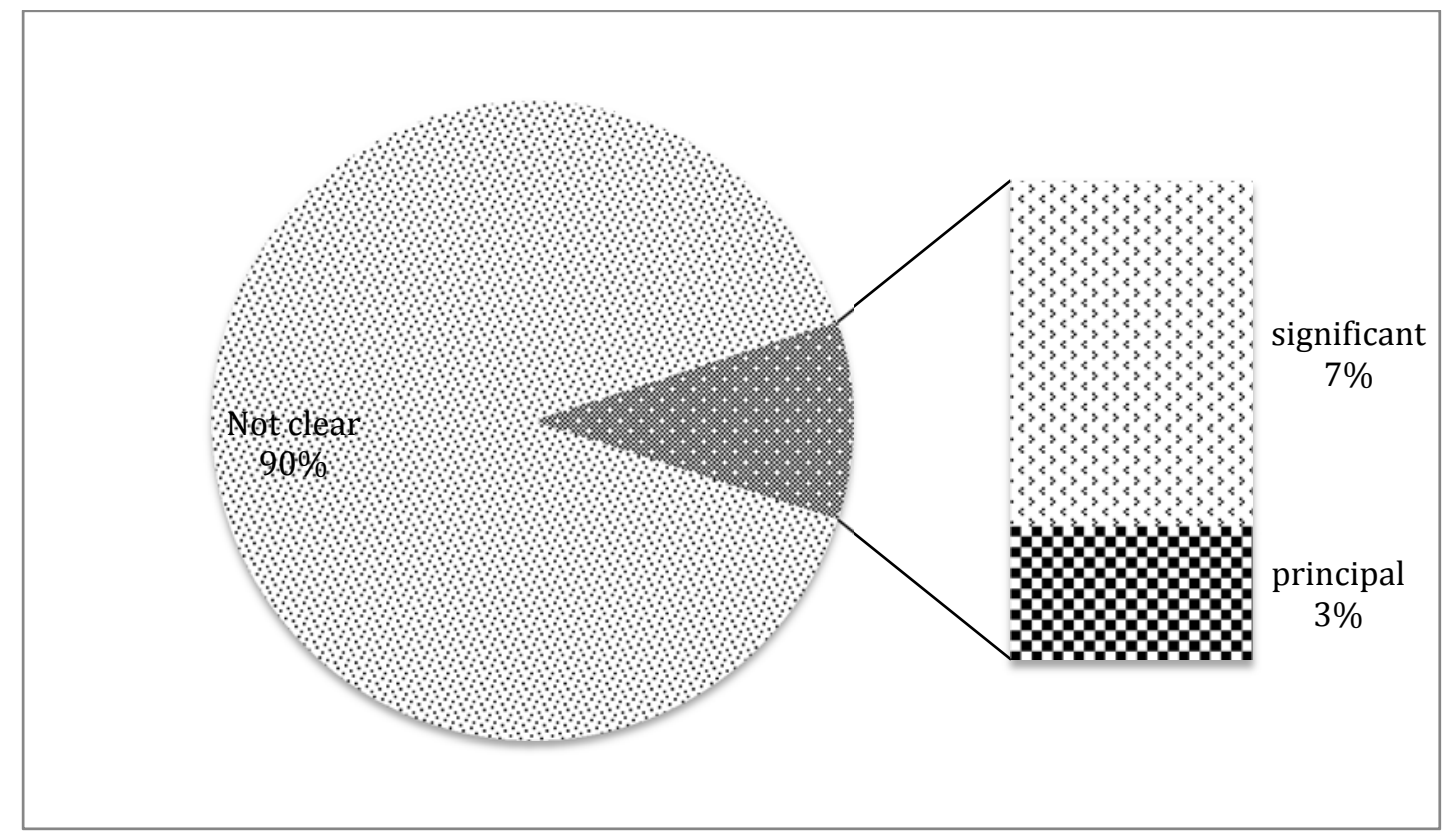

Source: Data based on Tierney et al. (2011).

Figure 4: Environmental issues in disbursed funds

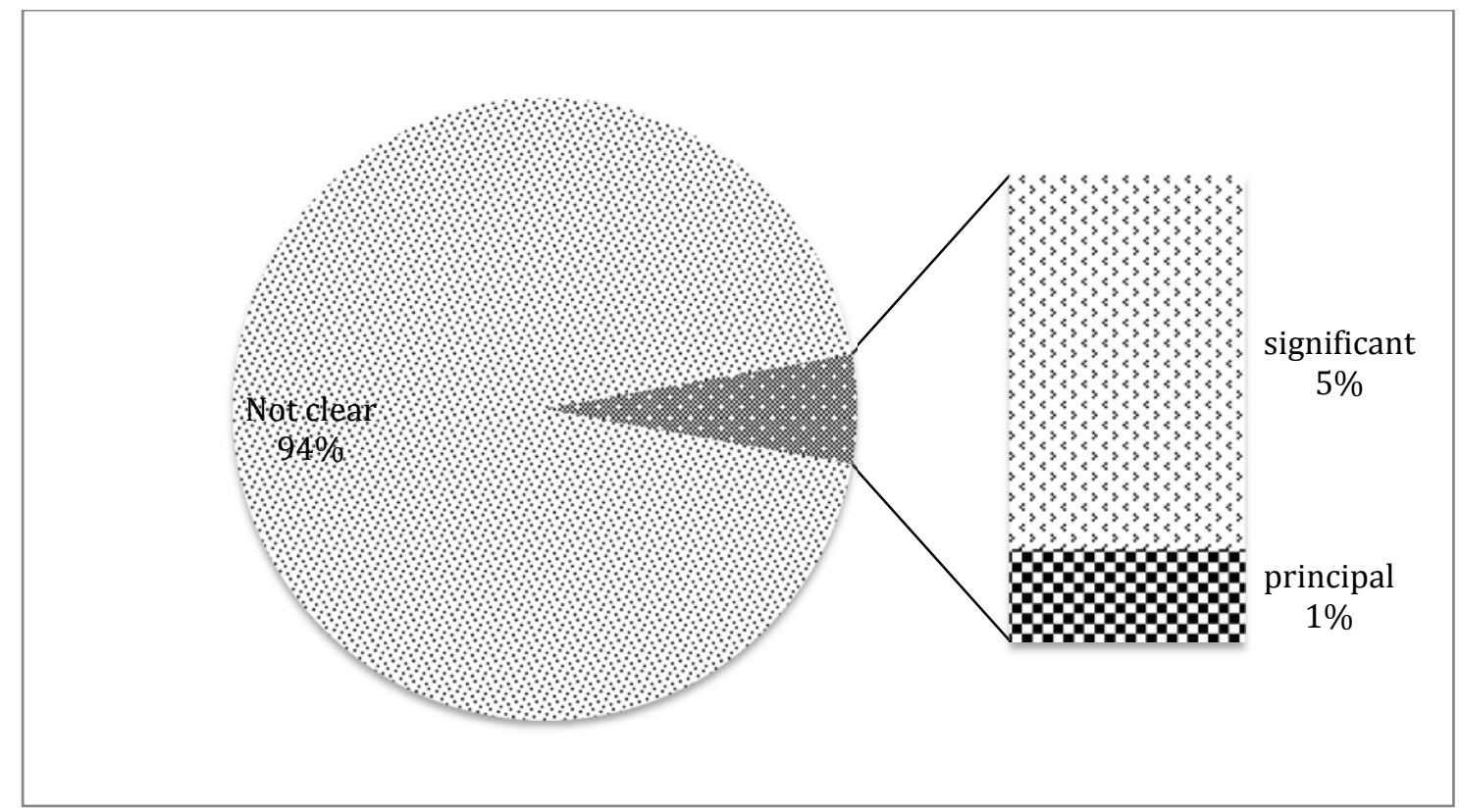

Source: Data based on Tierney et al. (2011).

The results of both committed and disbursed funds over the time, taking into account the variable environment, reveal that there is no clear pattern of relevance of environmental issues over the time (Figures 5 and 6). There is an odd and discontinuous trend, where there are some specific years in which environmental issues have been clearly targeted with significant amounts of funds. Coincidently, most of these specific years were environmental issues were targeted are mainly the ones in which the country has been heavily affected by environmental stresses, like droughts or floods. For instance, in 2000 a severe flood hit the country and in 2005, there was a general drought across the country, and as shown in the figures below, there are significant amounts devoted to environmental issues. These findings suggest that the majority of interventions on environmental 
issues of a are more reactive type, responding to specific events of environmental shocks more in form of relief than of planned actions.

Figure 5: Trend of relevance of environment in commitments

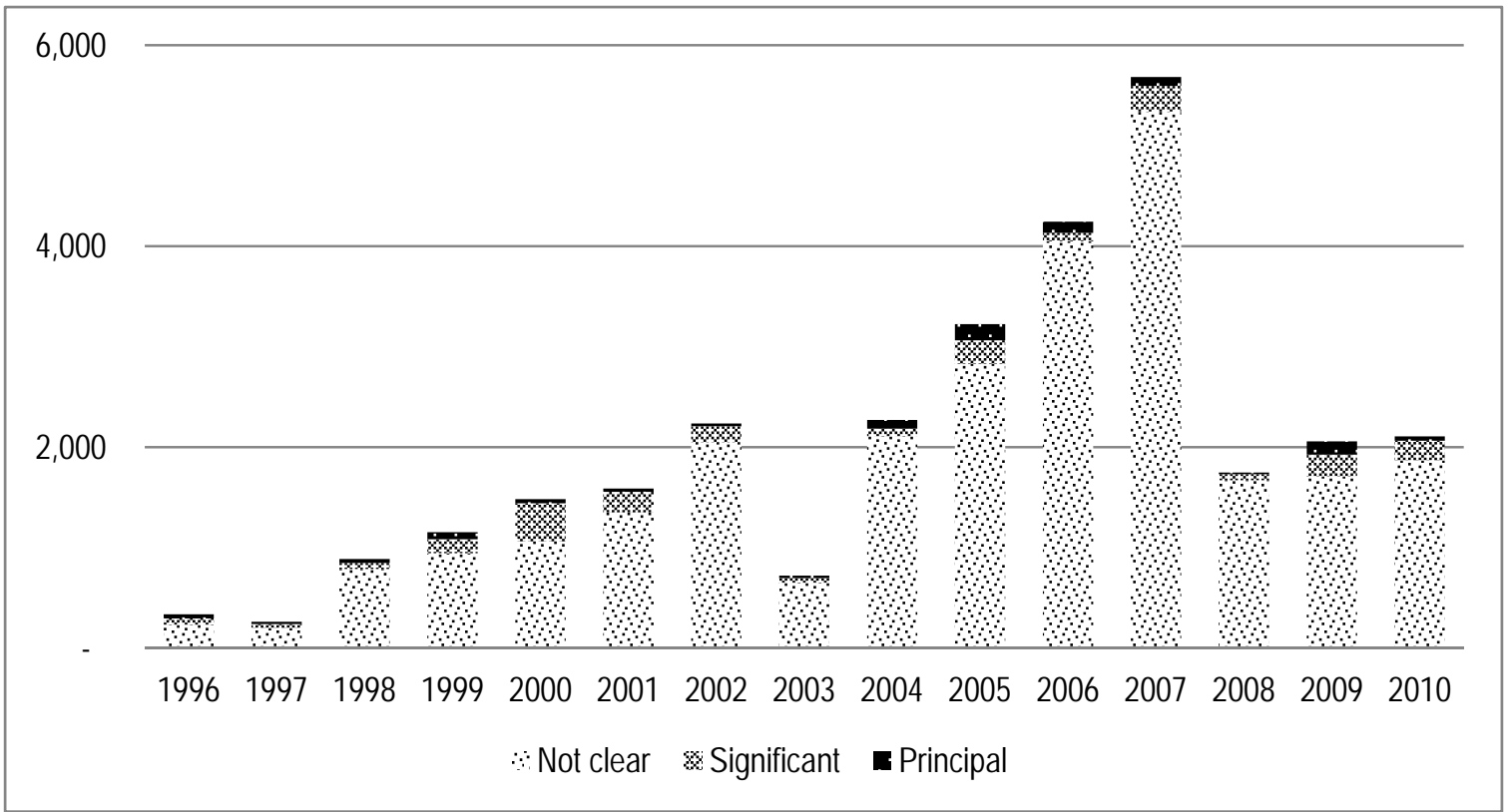

Source: Data based on Tierney et al. (2011).

Figure 6: Trend of relevance of environment in disbursements

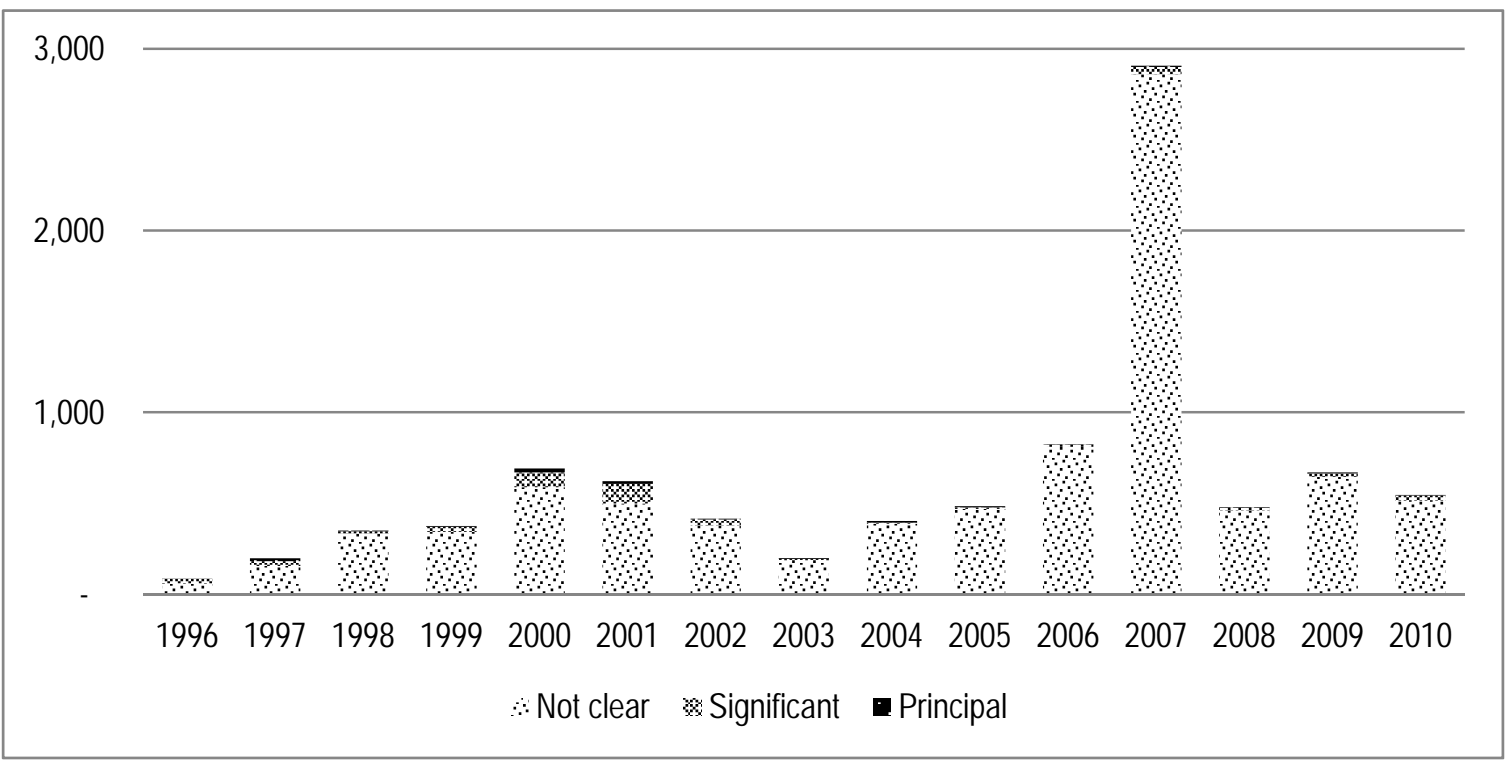

Source: Data based on Tierney et al. (2011).

Nevertheless, it is known that as a result of the shift in the country's approach to poverty, giving more attention to the relationship between poverty and environment, the poverty and environment initiative (phase I) was launched in 2005. The overall objective of this initiative was to increase the capacity to mainstream the links between poverty and environment. Taking into account this fact and the other initiatives/programmes that have been carried out across the country, one would expect an increasing trend in the relevance of environmental issues in both 
commitment and disbursement from a certain point of time. Yet, in the results, the shift in the country's national strategies in the realm of environment is not evident. Probably, due to the crosscutting nature of environmental issues across sectors. There might be some projects in some sectors in which the environment has been addressed, but not captured as environmentally relevant during data codification of the projects because it was not clearly evident in the information used for codification. For instance, the administrative and institutional costs embedded in programmes that cross-cut the sectors, which may closely be linked to environmental issues are not classified as such in the database; the same applies to other ambiguous projects that somehow tackle environmental issues but are not clearly specified in the objectives.

Furthermore, funding addressing environmental issues in Mozambique is not only controlled by MICOA, but environmental issues are also mainstreamed in other relevant sectors. Due to the cross-cutting nature of the environment, it is interesting to have an idea of how much funds address environmental issues in different sectors.

According to Figures 7 and 8 al most all the sectors present some degree of environmental considerations. In the sectors of biodiversity and environment, environmental issues are a principal consideration in terms of both commitments and disbursements. In addition, the sectors of agriculture, fisheries, rural development, and water resources and sanitation present a significantly high consideration of environmental issues. However, it can be noticed that for the majority of the sectors there was more consideration of environment in commitments than in disbursement. The sectors of fisheries, industry, and rural development are the only ones where the shares of environmental considerations in disbursements are relatively higher than in the commitments.

Figure 7: Relevance of environment in committed funds by sector

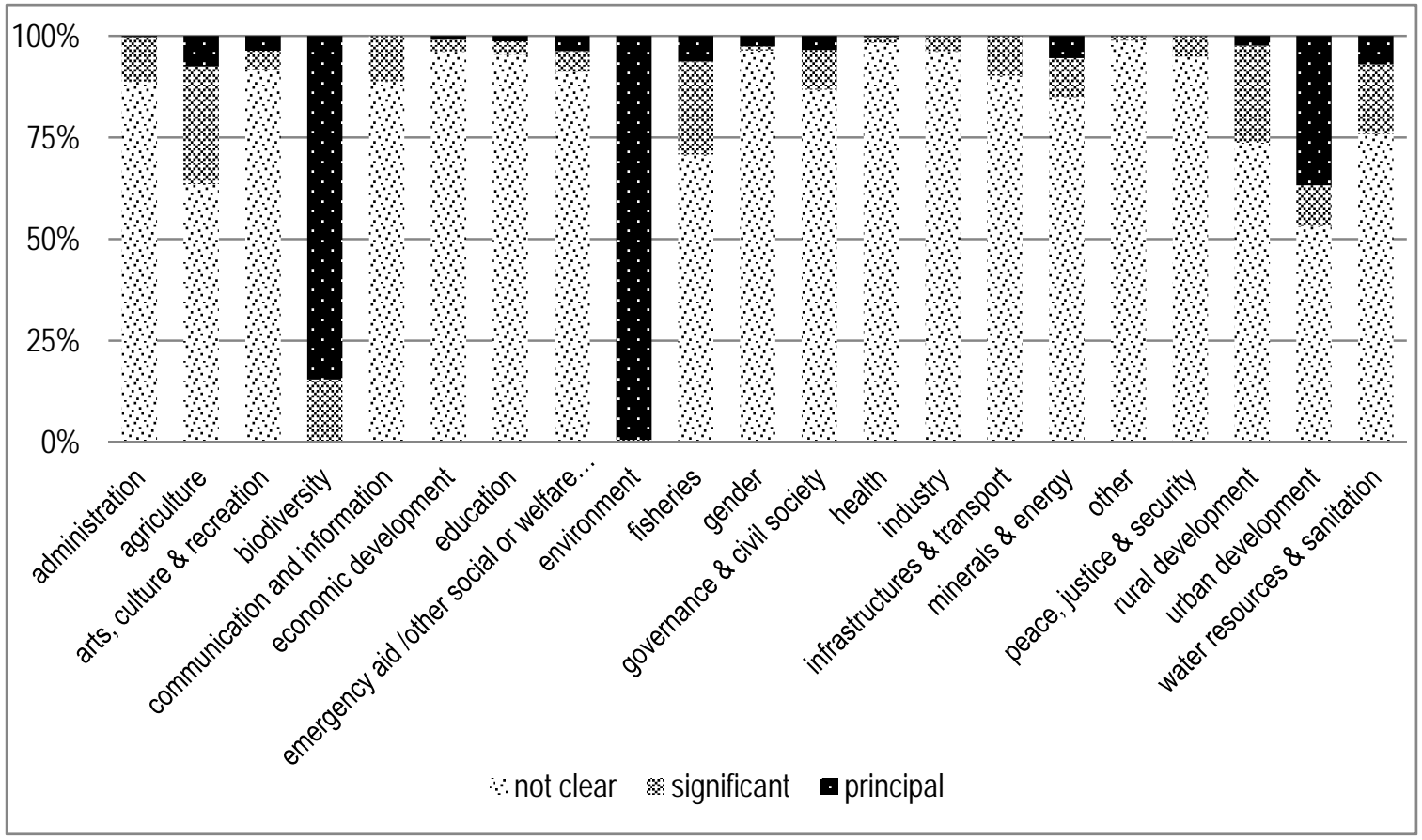

Source: Data based on Tierney et al. (2011). 


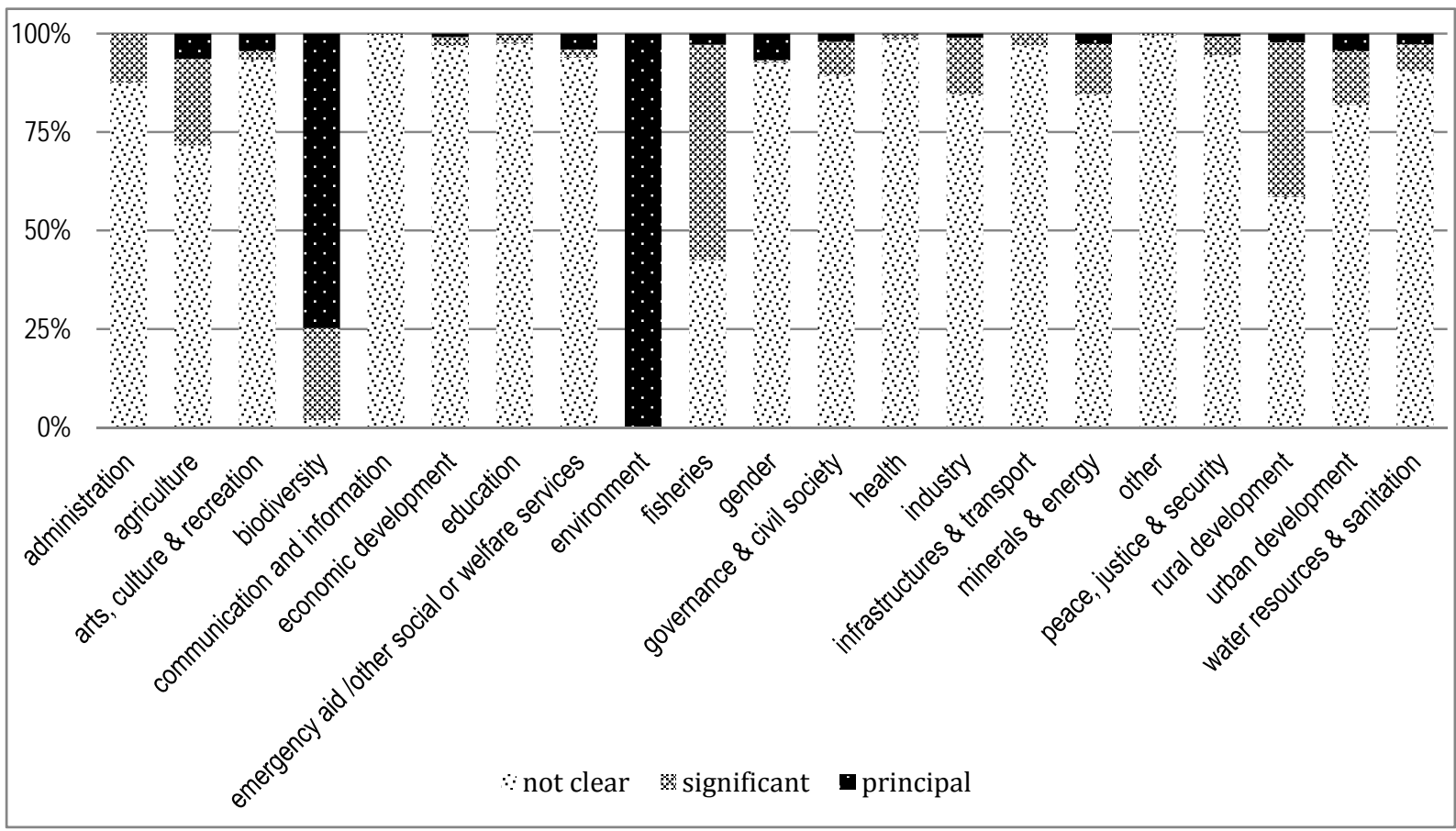

Source: Data based on Tierney et al. (2011).

The environmental donors in Mozambique during the period 1996-2010 are presented in Table 2. Some donors are relevant in terms of overall funding in Mozambique, however, they become less important under the environmental lens. The example of those includes Liechtenstein, Iceland, and the ACBF, which are important donors in general (Table 1). However, they become unnoticeable when considering environmental issues (Table 2). Among the environmental donors, Norway, Sweden, Ireland, Italy, Portugal, US, and Spain stand out with individual disbursements over five per cent of the total amount disbursed in projects addressing environmental issues. Altogether these donors account for about 61 per cent of the amount disbursed for environmental projects in the period of study.

In terms of actualization of commitments in environmental projects, EC, Chile, Switzerland, Global Environmental Fund (GEF), Nordic Development Fund (NDF), and World Food Programme (WFP) stand out as they disbursed more than 50 per cent of the amount of their commitments. The group of donors, such as Norway, Sweden, Finland, Denmark, Australia, Japan, UNICEF, Canada, France, Islamic Development Bank (ISDB), OPEC (Organization of the Petroleum Exporting Countries) Fund for International Development (OFID), and Joint United Nations Programme on HIV/AIDS (UNAIDS), although disbursed less than 50 per cent of the amount they committed, the level of actualization of their commitments was greater than the overall level of 18 per cent. The remaining major donors present lower level of actualization of their commitment than the overall level. 
Table 2: Relevant environmental donors in Mozambique, 1996-2010

\begin{tabular}{|c|c|c|c|c|c|c|}
\hline Rank & Donor & $\begin{array}{c}\text { Amount } \\
\text { committed (US\$ } \\
\text { 2009) }\end{array}$ & $\begin{array}{l}\text { Share of total } \\
\text { commitment (\%) }\end{array}$ & $\begin{array}{l}\text { Amount disbursed } \\
\text { (US\$ 2009) }\end{array}$ & $\begin{array}{c}\text { Share of total } \\
\text { disbursement } \\
\text { (\%) }\end{array}$ & $\begin{array}{c}\text { Acomplish- } \\
\text { ment of } \\
\text { commitment } \\
(\%) \\
\end{array}$ \\
\hline 1 & Norway & $275,000,000$ & 8.74 & $77,200,000.00$ & 13.86 & 28.07 \\
\hline 2 & Sweden & $156,000,000$ & 4.96 & $68,600,000.00$ & 12.32 & 43.97 \\
\hline 3 & Ireland & $442,000,000$ & 14.05 & $48,300,000.00$ & 8.67 & 10.93 \\
\hline 4 & Italy & $279,000,000$ & 8.87 & $45,300,000.00$ & 8.13 & 16.24 \\
\hline 5 & Portugal & $330,000,000$ & 10.49 & $36,000,000.00$ & 6.46 & 10.91 \\
\hline 6 & United States & $221,000,000$ & 7.03 & $35,800,000.00$ & 6.43 & 16.20 \\
\hline 7 & Spain & $240,000,000$ & 7.63 & $30,300,000.00$ & 5.44 & 12.63 \\
\hline 8 & $\begin{array}{l}\text { Finland } \\
\text { European }\end{array}$ & $111,000,000$ & 3.53 & $25,900,000.00$ & 4.65 & 23.33 \\
\hline 9 & Community & $28,700,000$ & 0.91 & $23,800,000.00$ & 4.27 & 82.93 \\
\hline 10 & Germany & $307,000,000$ & 9.76 & $22,700,000.00$ & 4.08 & 7.39 \\
\hline 11 & Switzerland & $31,200,000$ & 0.99 & $17,800,000.00$ & 3.20 & 57.05 \\
\hline 12 & Chile & $20,100,000$ & 0.64 & $15,200,000.00$ & 2.73 & 75.62 \\
\hline 13 & Belgium & $93,400,000$ & 2.97 & $14,700,000.00$ & 2.64 & 15.74 \\
\hline 14 & Denmark & $66,100,000$ & 2.10 & $13,100,000.00$ & 2.35 & 19.82 \\
\hline 15 & Australia & $35,400,000$ & 1.13 & $12,300,000.00$ & 2.21 & 34.75 \\
\hline 16 & Japan & $22,300,000$ & 0.71 & $10,200,000.00$ & 1.83 & 45.74 \\
\hline 17 & UNICEF & $40,600,000$ & 1.29 & $9,297,521.00$ & 1.67 & 22.90 \\
\hline 18 & Canada & $20,800,000$ & 0.66 & $8,996,690.00$ & 1.62 & 43.25 \\
\hline 19 & United Kingdom & $72,900,000$ & 2.32 & $8,053,209.00$ & 1.45 & 11.05 \\
\hline 20 & France & $26,300,000$ & 0.84 & $7,605,803.00$ & 1.37 & 28.92 \\
\hline 21 & UNFPA & $43,500,000$ & 1.38 & $7,514,676.00$ & 1.35 & 17.28 \\
\hline 22 & Austria & $79,100,000$ & 2.51 & $7,108,999.00$ & 1.28 & 8.99 \\
\hline 23 & UNDP & $29,200,000$ & 0.93 & $3,744,999.00$ & 0.67 & 12.83 \\
\hline 24 & The Netherlands & $52,600,000$ & 1.67 & $3,574,747.00$ & 0.64 & 6.80 \\
\hline 25 & ISDB & $6,233,926$ & 0.20 & $1,132,204.00$ & 0.20 & 18.16 \\
\hline 26 & AFDB & $36,600,000$ & 1.16 & $550,164.40$ & 0.10 & 1.50 \\
\hline 27 & GEF & 605,735 & 0.02 & $503,809.60$ & 0.09 & 83.17 \\
\hline 28 & BADEA & $14,600,000$ & 0.46 & $370,574.20$ & 0.07 & 2.54 \\
\hline 29 & OFID & 795,931 & 0.03 & $307,161.10$ & 0.06 & 38.59 \\
\hline 30 & UNAIDS & 980,340 & 0.03 & $279,381.00$ & 0.05 & 28.50 \\
\hline 31 & NDF & 277,545 & 0.01 & $277,545.20$ & 0.05 & 100.00 \\
\hline 32 & World Bank & $2,068,204.00$ & 0.07 & $234,134.50$ & 0.04 & 11.32 \\
\hline 33 & WFP & 148,510 & - & $148,509.50$ & 0.03 & 100.00 \\
\hline 34 & Brazil & $40,300,000$ & 1.28 & $19,440.57$ & - & 0.05 \\
\hline 35 & Luxembourg & $1,467,475$ & 0.05 & $6,527.92$ & - & 0.44 \\
\hline
\end{tabular}

Source: Data based on Tierney et al. (2011).

The AidData interestingly specifies the relevance of the projects regarding to others aspects linked to environment, including biodiversity, climate change, and desertification. In the following subsections the relevance of these issues in external funding is presented. 


\subsection{Significance of biodiversity in external funding}

The analysis shows a cumulative amount of US $\$ 506$ million committed to address biodiversity issues during the period 1996-2010; however, only US\$100 million were actually disbursed. This indicates a level of actualization of commitments among the projects addressing biodiversity issues of about 20 per cent. In addition, the total aid shares indicate that for both externally committed and disbursed funds, the share allocated to biodiversity issues is very low (Figures 9 and 10). Little over 1 per cent of the committed amount addresses biodiversity as a significant issue and less than 1 per cent tackles explicitly biodiversity as a main objective (Figure 9). A similar event is also notable for biodiversity issues, where the relevance of biodiversity issues relative to other development issues is even smaller in the disbursed funds when compared to committed amounts (Figure 10).

Figure 9: Biodiversity issues in committed funds

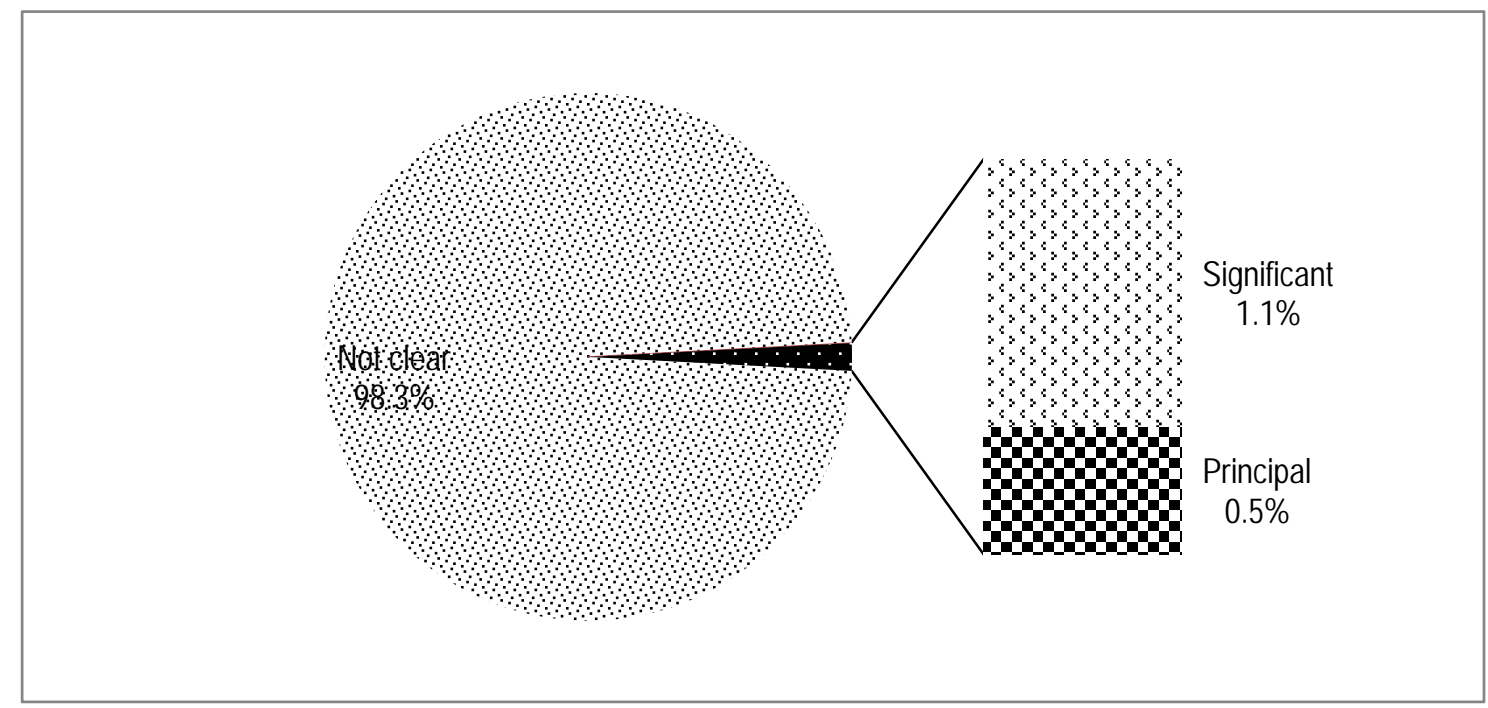

Source: Data based on Tierney et al. (2011).

Figure 10: Biodiversity issues in disbursed funds

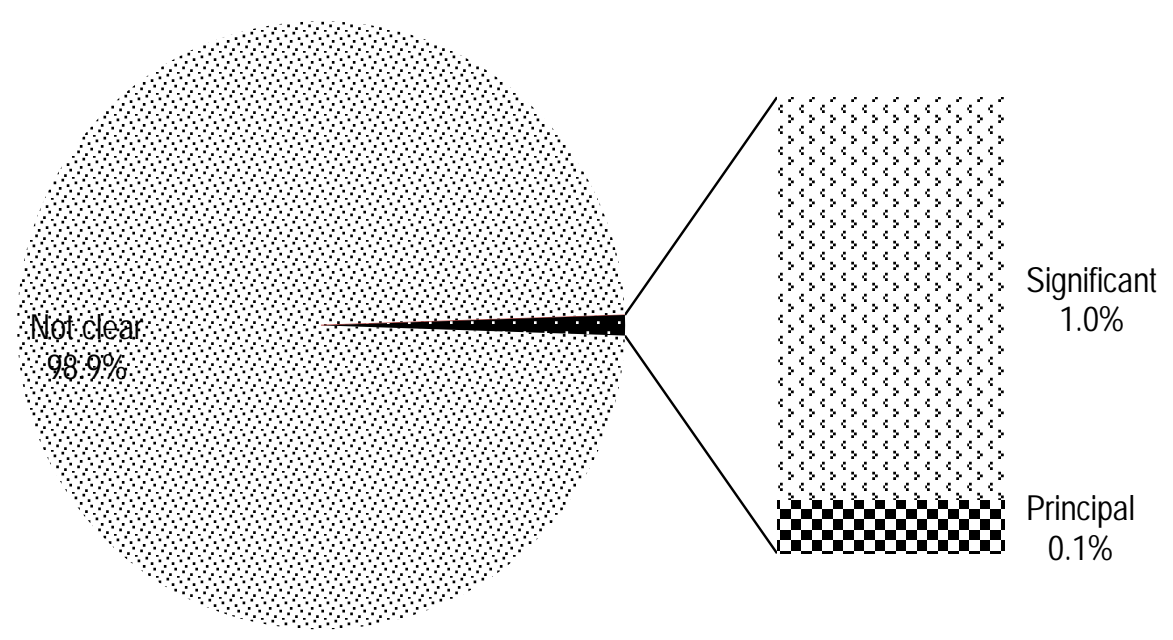

Source: Data based on Tierney et al. (2011). 
Besides the sectors of environment and biodiversity, only agriculture, fisheries, and rural development present significant degrees of consideration of biodiversity issues in terms of both commitments and disbursements (Figures 11 and 12). Apart from the environmental sector, the majority of sectors where biodiversity is relevant, such as fisheries, biodiversity, agriculture and rural development, the shares of biodiversity considerations in disbursements are relatively higher than in the commitments.

Figure 11: Relevance of biodiversity in committed funds by sector

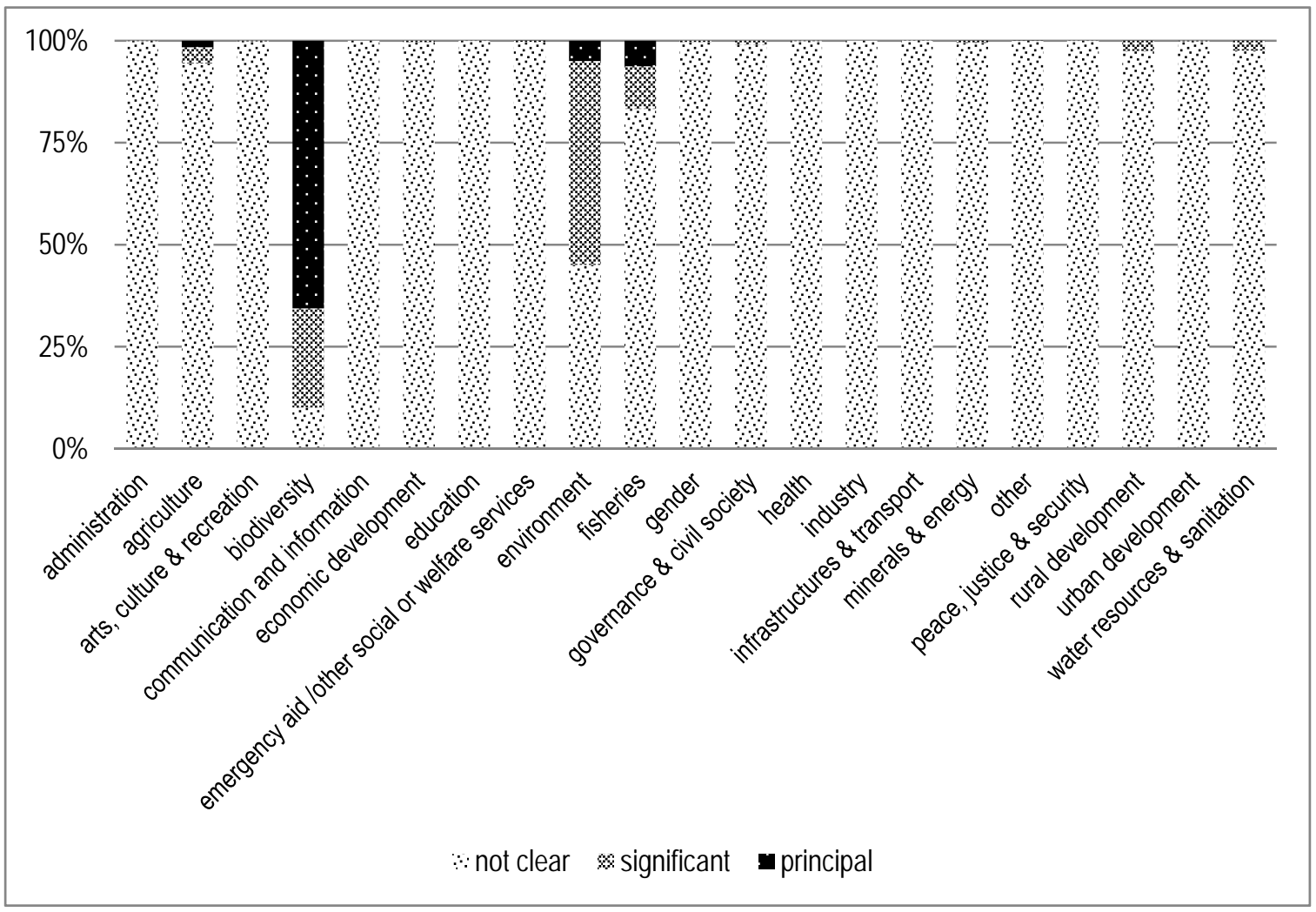

Source: Data based on Tierney et al. (2011). 


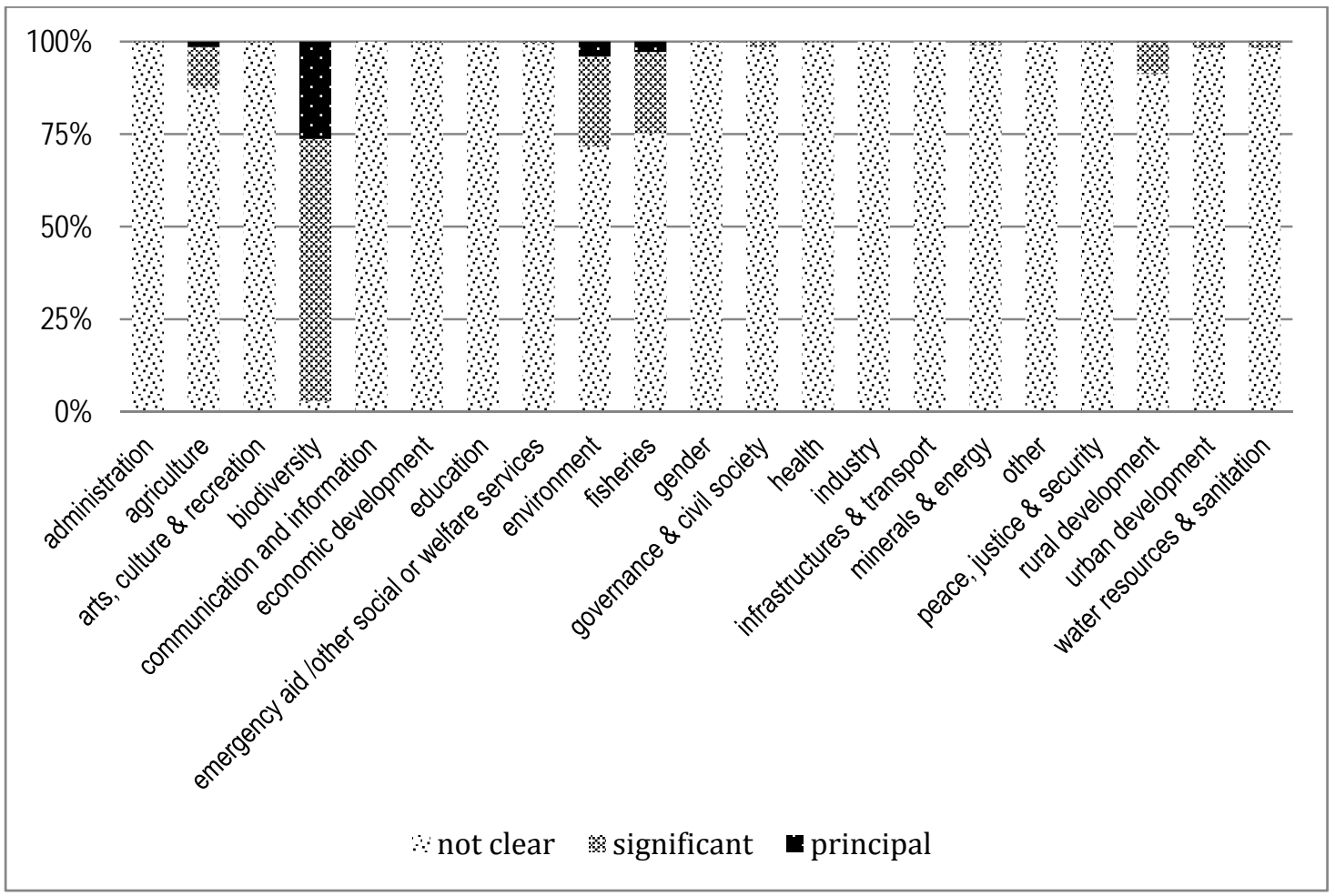

Source: Data based on Tierney et al. (2011).

\subsection{Significance of desertification in external funding}

The results indicate that a cumulative amount of US $\$ 360.5$ million were committed to address desertification issues during the period 1996-2010; however, only US\$65 million were actually disbursed. The level of accomplishment of commitments among the projects addressing desertification issues is about 18 per cent. In addition, the total aid shares indicate that for both externally committed and disbursed funds, the share allocated to desertification issues is also very low (Figures 13 and 14). Little over one per cent of the committed amount during this period addresses desertification as a significant issue and a negligible share of funds tackles explicitly desertification as a main objective (Figure 13). The relevance of desertification issues relatively to other development issues is also smaller in the disbursed funds when compared to committed amounts. About 1.2 per cent of the total committed funds are addressing desertification; however, only 0.7 percent of disbursed funds address desertification. 


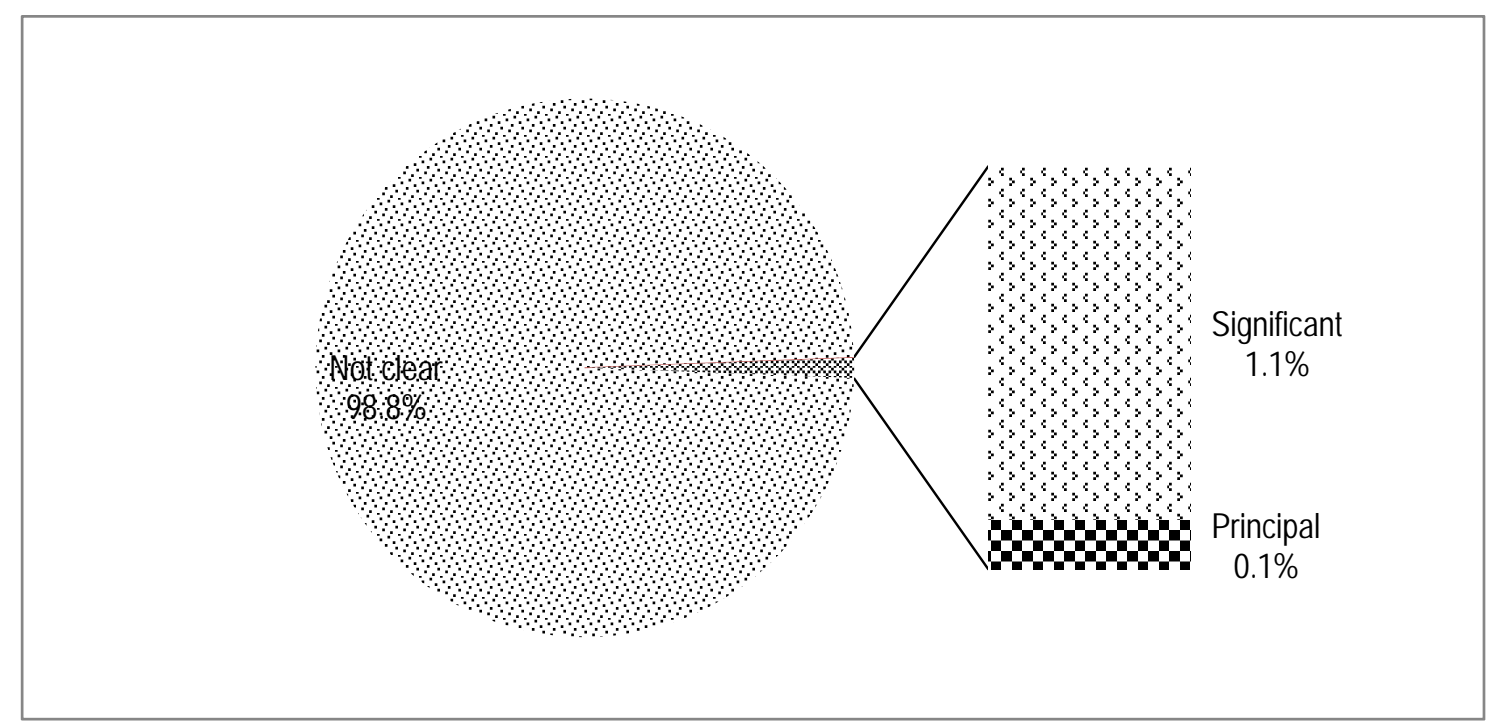

Source: Data based on Tierney et al. (2011).

Figure 14: Desertification issues in disbursed funds

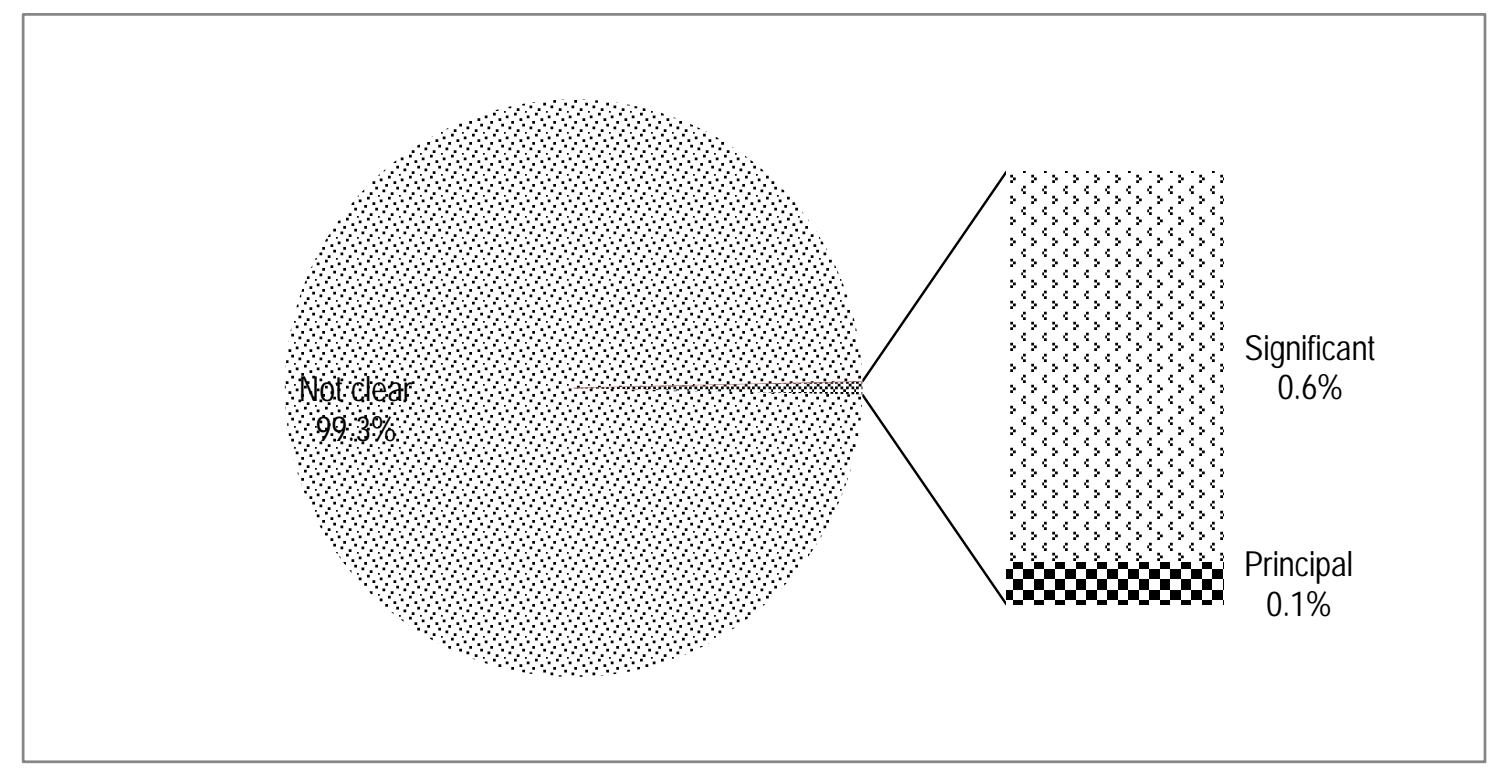

Source: Data based on Tierney et al. (2011).

Besides the sectors of environment and biodiversity, which present significant consideration of desertification issues, only agriculture, governance and civil society, and rural development present some degree of considerations of desertification issues in terms of both commitments and disbursements (Figures 15 and 16). Apart from the environmental sector and governance and civil society, the remaining sectors with some degree of consideration of desertification present relatively higher shares of considerations of this environmental issue in the disbursements relatively to its committed counterpart. 
Figure 15: Relevance of desertification in committed funds by sector

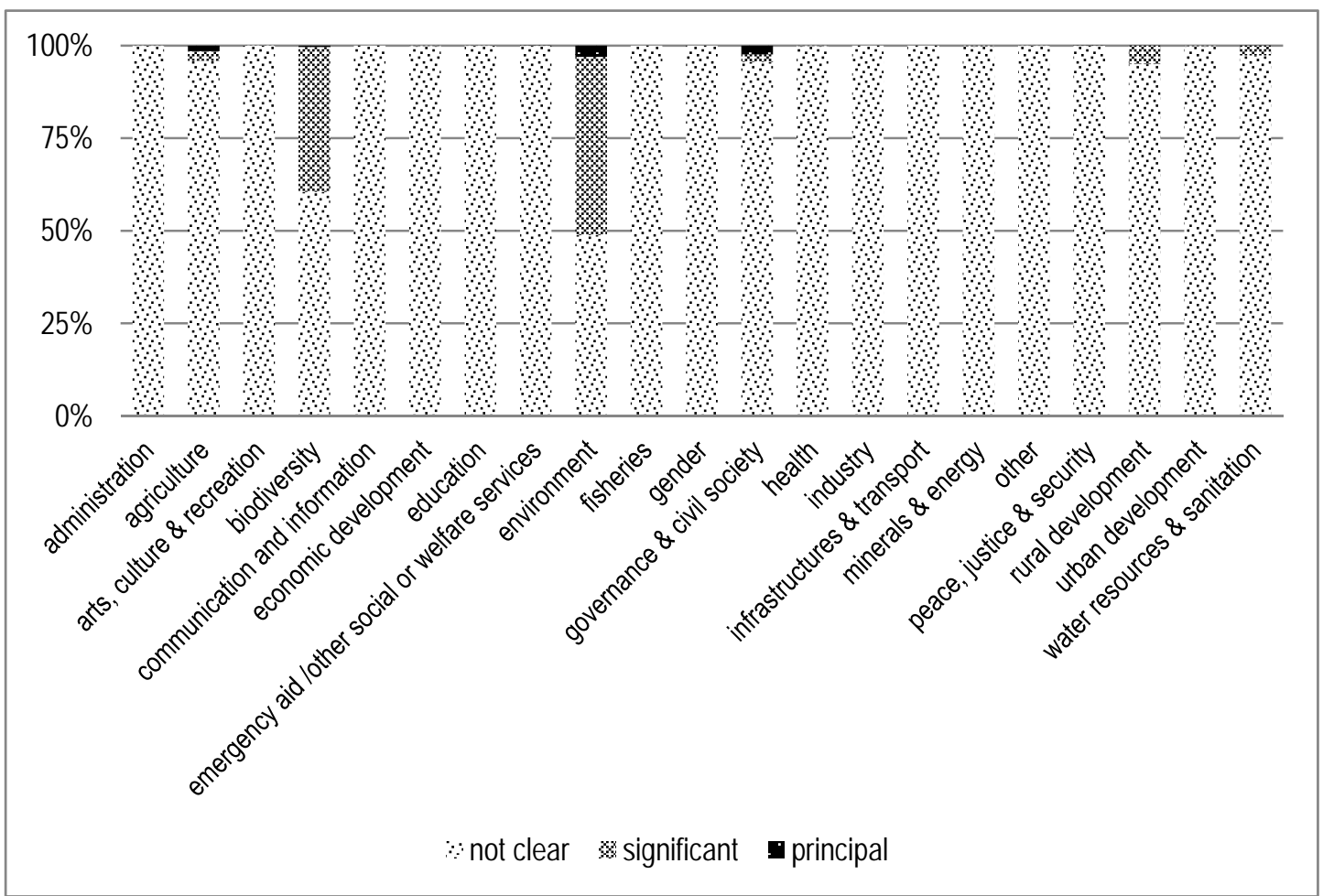

Source: Data based on Tierney et al. (2011).

Figure 16: Relevance of desertification in disbursed funds by sector

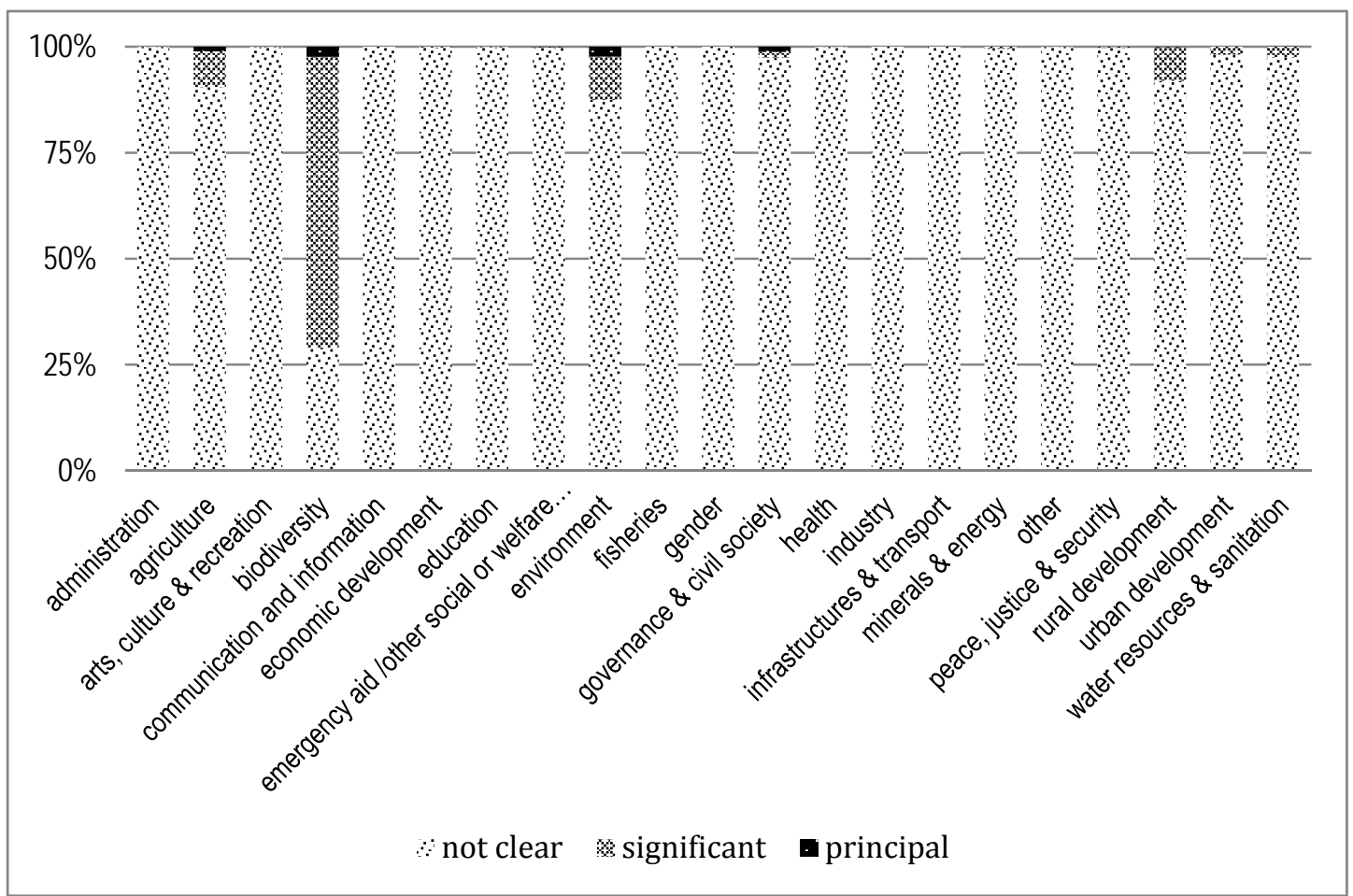

Source: Data based on Tierney et al. (2011). 


\subsection{Significance of climate change in external funding}

The results reveal a cumulative amount of US $\$ 618$ million committed to address climate change issues during the period 1996-2010. However, only US $\$ 100$ million were actually disbursed to address the issue. This indicates a level of actualization of commitments among the projects addressing climate change of about 16 per cent. In addition, the total aid shares indicate that for both externally committed and disbursed funds, the share allocated to climate change issues is also low (Figures 17 and 18). About little over 1 per cent of the committed amount during this period addresses climate change as a significant issue and less than 1 per cent tackles explicitly climate change as the main objective (Figure 17).

Figure 17: Climate change issues in committed funds

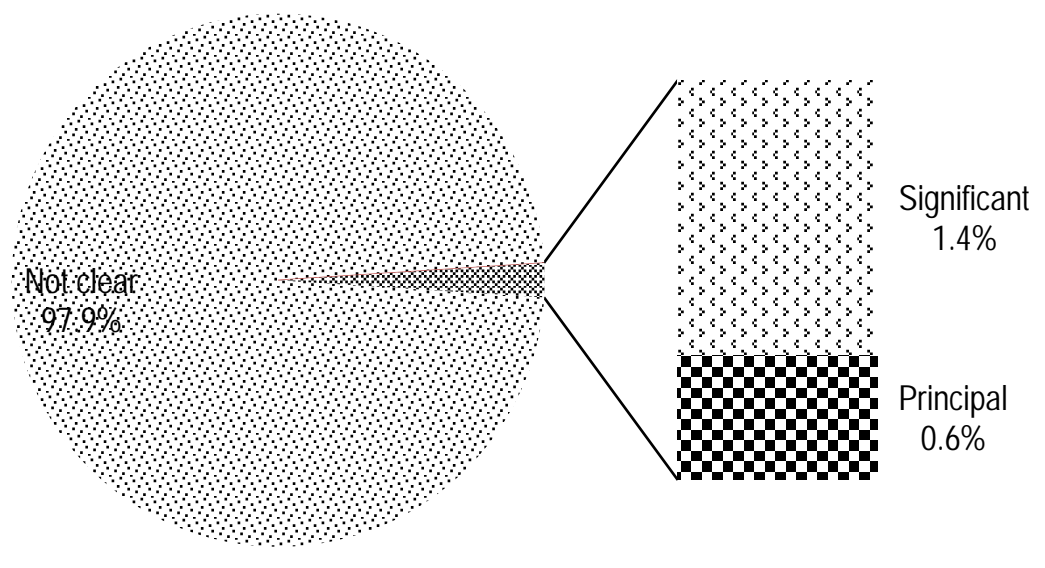

Source: Data based on Tierney et al. (2011).

Figure 18: Climate change issues in disbursed funds

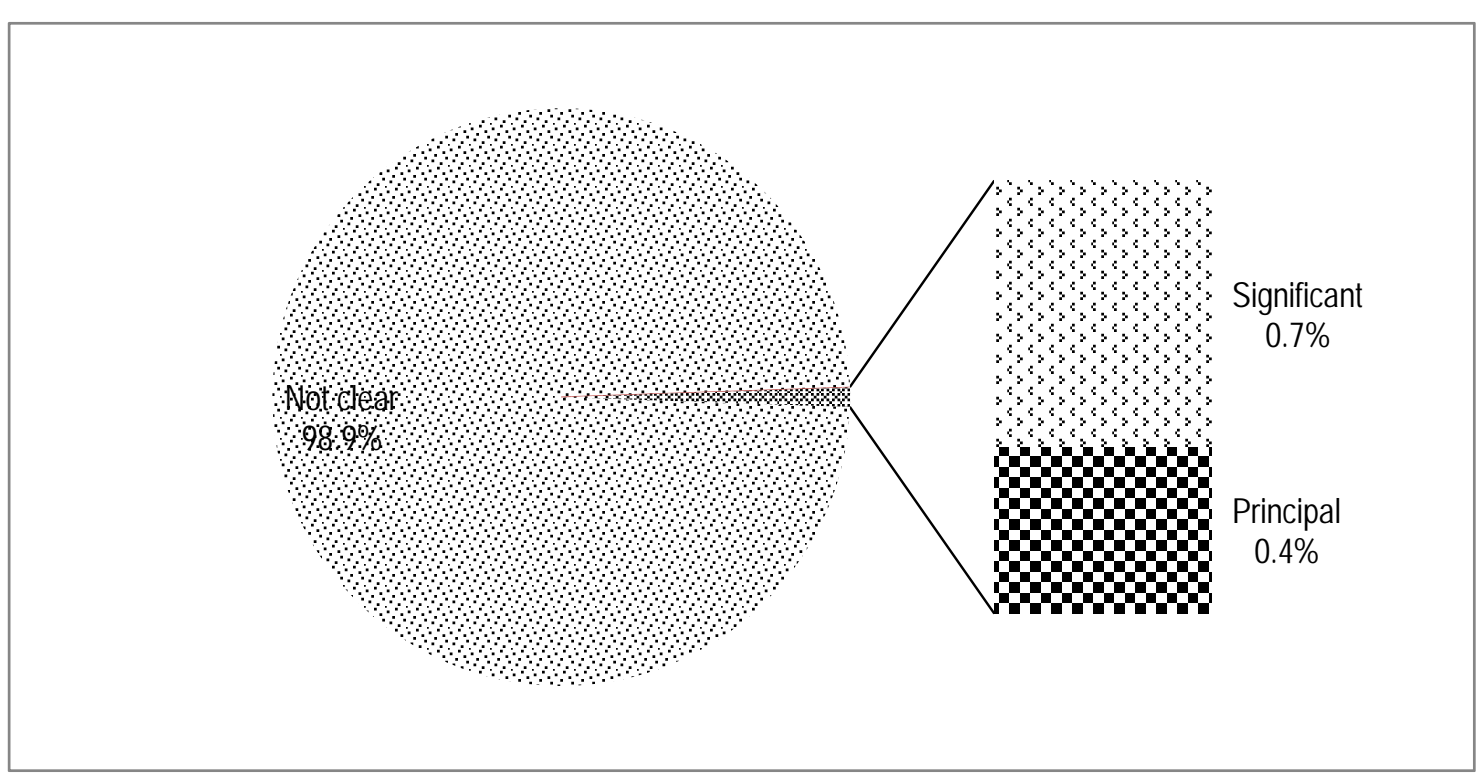

Source: Data based on Tierney et al. (2011). 
Comparing the three environmental issues discussed in the study, climate change is a top priority in planning. The shares of funds committed to climate change are relatively higher when compared to commitments in biodiversity and desertification.

Besides the sectors of environment and biodiversity, which present significant consideration of climate change aspects, only agriculture, fisheries, minerals and energy, and rural development present some degree of considerations of climate issues (Figures 19 and 20). In biodiversity, fisheries and rural development sectors, the considerations of climate change in the disbursements are relatively higher than in the commitments.

Figure 19: Relevance of climate change in commitment by sector

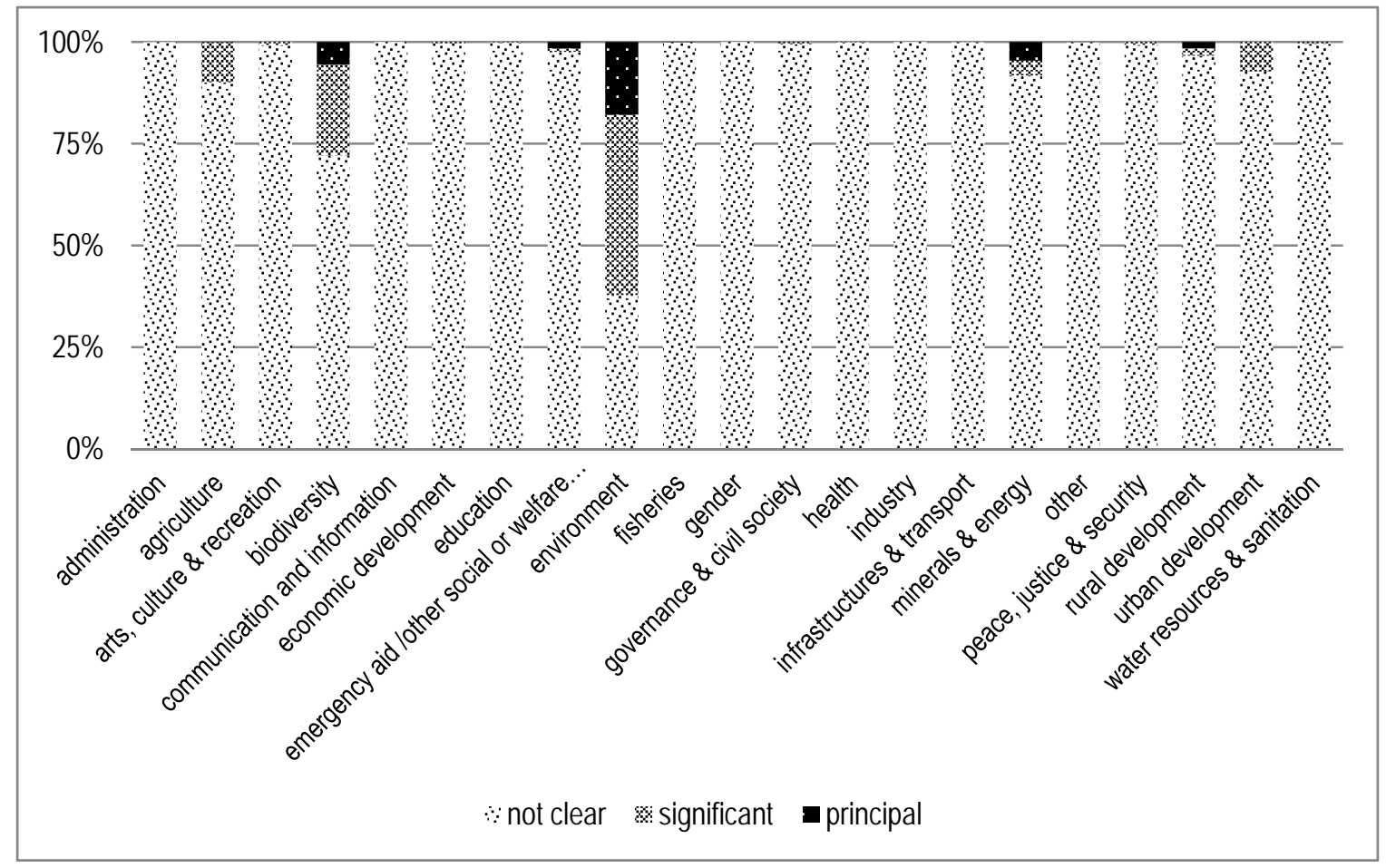

Source: Data based on Tierney et al. (2011). 


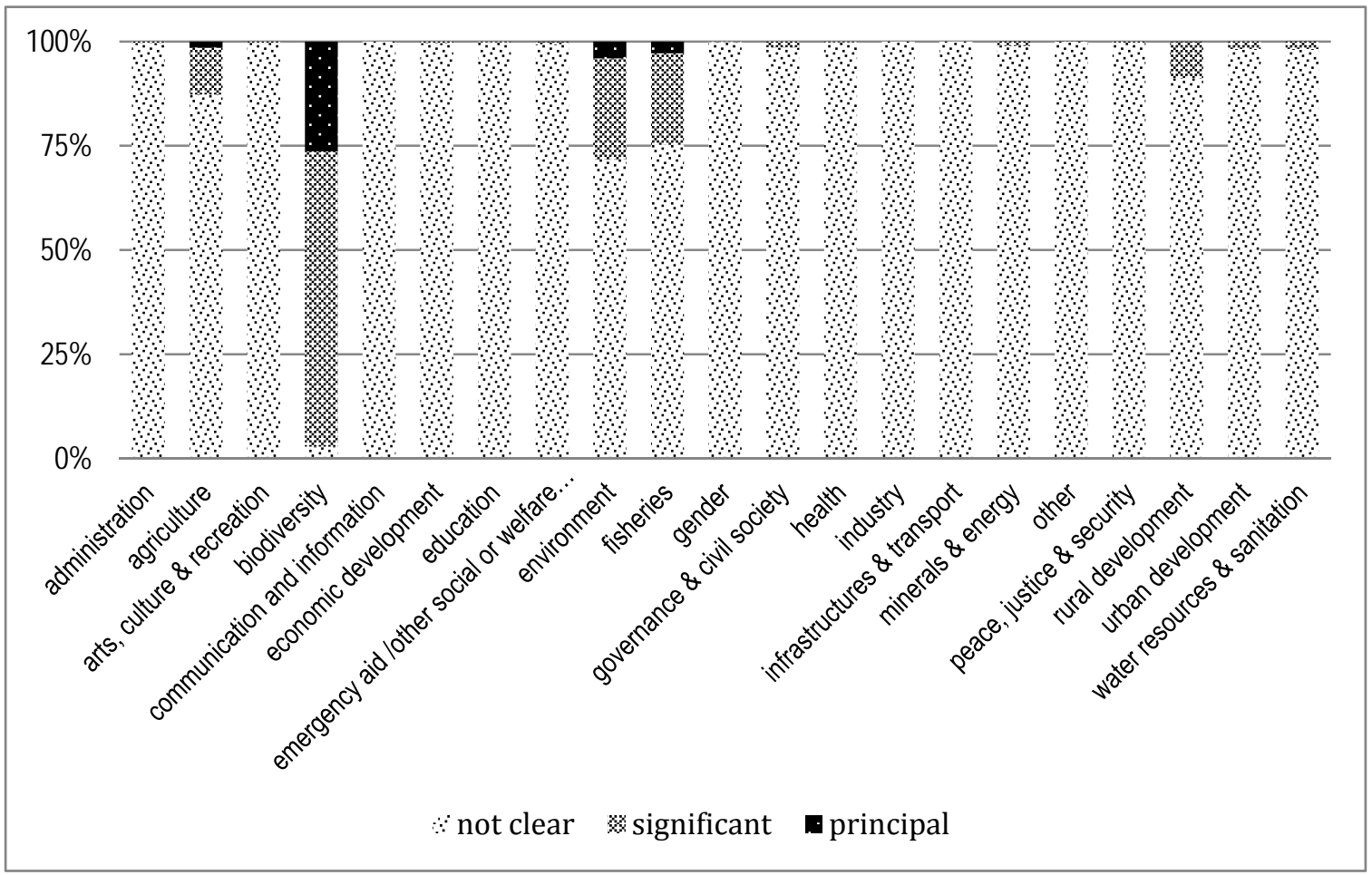

Source: Data based on Tierney et al. (2011).

\section{$7 \quad$ Perspectives of the development partners on aid and environment}

This section of the paper is mainly based on the responses and documents provided by the development partners in the second stage of the study; their perceptions regarding the relevance of environmental issues are presented in the sub-sections. ${ }^{2}$

\subsection{Environmental versus non-environmental aid}

The development partners consider all funds linked to projects dealing directly with natural resources management and/or which include environmental considerations in their implementation as environmental aid. According to the respondents, both environmental and nonenvironmental aid requires serious consideration. In their points of view, the country still has high levels of poverty incidence and the needs in basic services are still critical for economic development. Therefore the non-environmental sectors require more support than the environmental sectors. However, given availability and likely increase in dependency on natural resources extractions and appropriate considerations of environmental issues are becoming more relevant for sustainable use of the resources. Environmental issues need to be mainstreamed in all development efforts, and all the sectors of the economy should have environmentally sound policies and environmentally friendly practices. In the scale from 1 to 5,1 being unimportant and 5 very important, the respondents attribute a unanimous rate of 4 , which is an indication of a perception of the high importance of environmental consideration in donor support. The priority sectors for environmental consideration and the reason for their prioritization are presented in Table 3.

2 The interviews were conducted with USAID, CIDA and the Embassy of Ireland. 
Overall, the interviewed partners indicated that less than 20 per cent of their aid funds addressed environmental issues. However, they recognized that it was actually difficult to clearly disaggregate the environmental funds as they were mainly directed to support the overall budgets either at national or provincial level, or even more decentralized levels, rather than to specific sectors or projects. In this context, it is difficult to indicate the actual share addressing environmental issues, as the environment is cross-cutting and usually mainstreamed across sectors.

In terms of approaches used to decide the allocation of funds to specific sectors, the development partners employed mainly the combined demand and supply driven approaches. The interventions of the development partners were usually designed to address issues that met local realities, needs, and priorities in combination with the organization's strategic objectives and priorities. But, the impact assessment of the development partners' activities is usually aligned to its contribution in the implementation of the country's poverty reduction strategies and sectorial policies/strategies.

Regarding the opinion of the development partners whether non-environmental aid has or does not have an environmental impact, they said that non-environmental aid usually has environmental impacts, and they actively considered environmental impact of non-environmental funds in their decisions to expand the non-environmental aid. In a scale from 1 to 5,1 being the lowest and 5 the highest, the development partners provided an average of 4 for the environmental consideration in relation to other considerations in their decisions to extend non-environmental aid. This indicates a higher consideration of the environmental issues compared to other issues in non-environmental aid.

The development partners assessed the impact of different types of aid, in both welfare and environment, using a scale from 1 (less effective) to 5 (more effective). The results of the analyses clearly indicate that all types of aid were considered effective in both welfare and environment (with scores of at least 3.5). However, the degree of effectiveness is generally higher on welfare compared to environment (Figure 21). Still, there is no differentiation of the impact of the different types of aid on welfare. These findings are consistent with current development planning that set poverty alleviation as an ultimate goal. Yet, the effectiveness of environmental aid on the environment is relatively higher when compared to other types of aid. This is also reasonable since environmental aid might be targeting other development issues. 
Table 3: Priority sector for environmental considerations

\begin{tabular}{|c|c|c|}
\hline Rank & Sector & Reason of importance \\
\hline 1 & Agriculture & $\begin{array}{l}\text { Agricultural ecosystems and agro-biodiversity are the foundations of the country's economy. } \\
\text { Most of the poor population relies on agriculture for subsistence and basic needs. } \\
\text { Agriculture contributes to both emissions of greenhouse gas (GHG) and mitigation. Emissions of } \\
\text { GHG occur in agricultural pastures and forestry clearings when opening new farms contributing } \\
\text { to loss, degradation, and fragmentation of natural ecosystems, causing desertification and } \\
\text { reducing the potential for carbon sequestration. } \\
\text { Cultivated trees can contribute to carbon sequestration and prevent desertification. Climate- } \\
\text { smart agricultural practices can contribute greatly to environmental sustainability. }\end{array}$ \\
\hline 2 & Forestry & $\begin{array}{l}\text { Forestry ecosystems of Mozambique provide products, services, and non-material benefits on } \\
\text { which Mozambique's economy and development depend. } \\
\text { Important sector for subsistence (direct and indirect forest products), future employment growth, } \\
\text { soil conservation, carbon sequestration, etc. } \\
\text { Exploitation of high-value species and introduction of invasive non-native species might threaten } \\
\text { the environmental sustainability. }\end{array}$ \\
\hline 3 & $\begin{array}{l}\text { Land } \\
\text { resources }\end{array}$ & $\begin{array}{l}\text { Land is the resource base for the livelihood of the population. } \\
\text { Access to resources for poverty alleviation depends greatly on access to land resources. }\end{array}$ \\
\hline 4 & $\begin{array}{l}\text { Extraction } \\
\text { Industry }\end{array}$ & $\begin{array}{l}\text { The country is very rich in mineral resources, and the extraction industry is rapidly emerging, } \\
\text { calling for major environmental consideration of sustainability. }\end{array}$ \\
\hline 5 & $\begin{array}{l}\text { Water } \\
\text { resources }\end{array}$ & $\begin{array}{l}\text { Mozambique is a downstream country, greatly affected by both floods and droughts. } \\
\text { The country relies on good management of water resources for its subsistence and } \\
\text { development. } \\
\text { Also, Mozambique is subject to coastal erosion, often in urban or in very fertile areas. }\end{array}$ \\
\hline 6 & Fisheries & $\begin{array}{l}\text { The country is rich in aquatic and marine ecosystems that provide the ecosystem products, } \\
\text { services, and non-material benefits. } \\
\text { Due to the exodus from inland to coastal areas during the war, and to the current development } \\
\text { trends of coastal cities, subsistence of coastal communities relies on fisheries resources. } \\
\text { Also an important basis for the country's economic development. }\end{array}$ \\
\hline
\end{tabular}

Source: Donors' survey. 


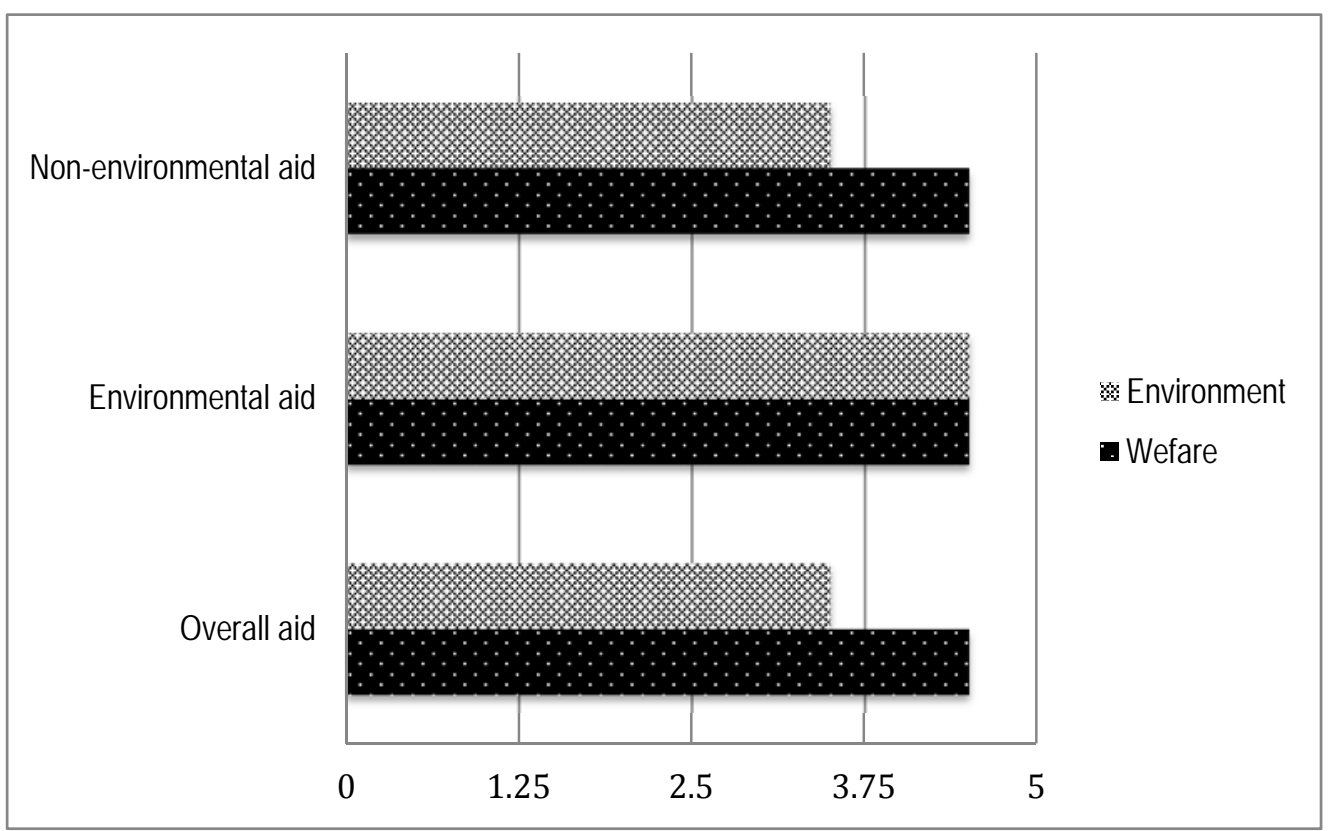

Source: Donors' survey.

In general, the development partners believe that different kinds of aid provide the expected results. To measure the impact of aid, the development partners have established joint monitoring and evaluation mechanisms with the local government, using country strategy indicators, policy dialogue, annual reviews, and project evaluations, among others.

\subsection{Relevant factors of failure or success of projects}

Development partners' perception of success of a project is based on the level of impact and achievement of the expected results. In addition, they also considered to be successful if the continuity and sustainability of interventions takes place even after the exit of partners' support. The measurement of progress is usually based on national tools, such as the household budget survey (Inquérito ao Orçamento Familiar), among others.

The interviewed partners were only able to mention successful environmental projects related to agriculture and land sectors. They mentioned that they were able to confirm that the host country shared the views of success regarding those projects during political and technical dialogue with government partners and other stakeholders. The success factors of the projects included visible impacts in the specific targets, such as increased access to land resources; increased awareness regarding country land legal framework and rights; increased access of potable water and improved sanitation, as well as increased adoption of improved agricultural technologies. In addition, the projects were able to engine other development initiatives at the local level that have effects in other broader development issues such as nutrition, and food security, among others.

The key drivers for getting good impacts from projects identified by the development partners include: (i) the combination of demand and supply driven approaches in the allocation of funds which allow the alignment of partners' priorities with local priorities and to meet critical needs; (ii) mechanisms that enabling dialogue and concerted actions among partners at all levels. Still, lack of data and transparency, weak multi-sectorial co-ordination, and poor technical capacity for implementation are major obstacles identified by the development partners. 
Environment needs to be mainstreamed in all development projects while implementation needs to be assured and properly monitored; policies and strategies are not enough. Rather than broad and superficial, very specific and deep interventions are more manageable and tend to show more visible impacts. Learning and experience sharing across countries with similar interventions should be encouraged whenever possible; foreign experience can be useful if properly adapted to local contexts and needs.

\section{$8 \quad$ Final remarks}

1. Health, natural disasters management, agriculture, and water resources are the four important sectors concerning environmental aid.

2. Despite the extensive range of national strategies, action plans, and other legal instruments to respond to the environmental call, only 9 per cent of the overall aid flows are allocated to environment-related issues, from which only 3 per cent translates to actual environmental actions.

3. A greater share of environmental aid investment is mainly allocated for institutional support.

4. Resources allocated to environmental issues were not evenly distributed during the period of the study, as aid allocation peaked during specific years. This might indicate a tendency of allocating resources in relation to crisis.

5. The donors committed to finance Mozambique with a cumulative sum of at least US\$30,017 million (US\$2009), from which only 31 per cent were actually allocated.

6. From the top 30 donors in Mozambique, Ireland, Portugal, UNICEF, Spain, USA, and Sweden stand out with individual disbursements over 5 per cent of the total amount disbursed. Altogether, they add up to about 61 per cent of the total amount disbursed during the period of the study.

7. UNICEF, EC, Liechtenstein, Iceland, Chile, and ACBF stand out with a disbursement of more than 50 per cent of the amount committed.

8. Portugal, France, Switzerland, Belgium, Austria, Denmark, United Kingdom, and the World Bank, although disbursed less than 50 per cent of the amount committed, the level of realization of their commitment is greater than the overall level of 31 per cent.

9. Comparing the amount disbursed during the period 1996-2010 to tackle specific environmental issues, biodiversity benefited only from US\$100 million over a total of US $\$ 506$ million committed. Desertification issues received US $\$ 65$ million from US $\$ 360.5$ million which was committed.

10. US\$618 million were committed to address climate change issues, however, only US\$100 million were actually disbursed.

11. Development partners' perception indicated that less than 20 per cent of their aid funds addressed environmental issues, despite the difficulty to clearly disaggregate the environmental funds into different national, provincial, or even more decentralized levels, as well as into different sectors or projects.

12. According to the development partners, factors that determine the success of projects are: visible impacts of specific targets, such as increased access to land resources; increased awareness regarding the country's land law framework and rights; increased access of potable water and improved sanitation, increased adoption of improved agricultural technologies. 
13. There is a clear vision about the relevance of environmental issues and the need to mainstream them in all development projects. However, a systemic approach with concerted actions among development partners should be taken for an effective implementation. Additionally, an appropriate monitoring system is required in order to provide better visibility on the impacting actions and aid in the environmental field.

\section{References}

AEO (2012). 'Mozambique Outlook'. Available at: www.africaneconomicoutlook.org

Byers, B. (2001). 'Conserving the Miombo Ecoregion'. Final Reconnaissance Summary Report. Harare: WWF Southern Africa Regional Programme Office (SARPO).

Governo de Moçambique (1997). Lei No 20/97 de Mocambique. Maputo: Governo de Moçambique.

Governo de Moçambique (2004). Constituicao da Republica. Maputo: Governo de Moçambique.

Government of Mozambique (2012). National Report to the United Nations Conference on

Sustainable Development (Rio+20).

Marzoli, A. (2007a). 'National Forest Inventory’. Maputo: Direcção Nacional de Terras e Florestas.

Marzoli, A. (2007b). 'Integrated Assessment of Mozambican Forests'. Ministry of Agriculture, Italian Cooperation, and Agriconsulting.

MICOA (2010). 'Estratégia Nacional de Redução de Emissões por Desmatamento e Degradação (EN REDD)'. Draft Document. Maputo: MICOA.

MICOA (2007). 'Programa de Acção Nacional para Adaptação às Mudanças Climáticas (NAPA)'. Maputo: MICOA.

MPD/DNEAP (2010). 'Pobreza e Bem-Estar em Moçambique: Terceira Avaliação Nacional'. Maputo: MPD/DNEAP.

Timberlake, J., D. Goyder, F. Crawford, J. Burrows, G.P. Clarke, Q. Luke, H. Matimele, T. Müller, O. Pascal, C. de Sousa, and T. Alves (2011). 'Coastal Dry Forests in Northern Mozambique'. Plant Ecology and Evolution 144(2): 126-37.

Timberlake, J. and E. Chidumayo. (2011). 'Miombo Ecoregion Vision Report'. Occasional Publications in Biodiversity No. 20. Bulawayo: Biodiversity Foundation for Africa.

Tierney, M.J., D.L. Nielson, D.G. Hawkins, J. Timmons Roberts, M.G. Findley, R. Powers, B. Parks, S.E. Wilson, and R.L. Hicks (2011). 'More Dollars than Sense: Refining Our Knowledge of Development Finance Using AidData'. World Development 39(11): 1891-1906.

USAID (2013). 'Mozambique Environmental Threats and Opportunities Assessment'. Washington, DC: USAID. 